\title{
Building a Catholic church in 1950s Ireland: architecture, rhetoric and landscape in Dromore, Co. Cork, 1952-56
}

\author{
Richard J. Butler
}

For Rural History (draft, 10 Feb. 2020)

\begin{abstract}
Ireland has had a steadily declining population for more than a century. Economists and sociologists are agreed that, if this ominous trend continues, in another century the Irish race will have vanished much like the Mayans, leaving only their monuments behind them.
\end{abstract}

— John A. O'Brien, The Vanishing Irish: The Enigma of the Modern World (1954). ${ }^{1}$

This article explores the intellectual culture of Catholic architectural production in 1950s Ireland. In doing so, it speaks to a broad range of social, economic, and political aspects of Irish rural life and religious expression in what is often portrayed as a bleak decade marked by emigration, insularity, and conservative Catholicism. ${ }^{2}$ Its focus is an unusually well documented churchbuilding project in rural west Cork of the early 1950s - the Church of Mary Immaculate, Dromore, Co. Cork (Fig. 1) - and the life, work, and writings of the energetic parish priest who oversaw its construction, Canon Patrick Henchy (1888-1969) (Fig. 2). The building of Catholic churches in post-war Ireland was unusual by international standards: few other countries combined such intensive architectural production with such pronounced rural depopulation and economic stagnation. While the Church of England made redundant many hundreds of rural churches in the 1950s and 1960s, the Irish Catholic Church, by contrast, engaged in a wave of construction and renewal that rivalled the peaks of church building in the 1820s (around the time of Catholic Emancipation) and in the 1860s (in the era of Emmet Larkin's Irish 'devotional revolution'). ${ }^{3}$ This article uses the building of Dromore church to explore five key themes: first, it analyses cultural nationalism in 1950s Ireland from an ecclesiastical perspective. Second, it adds to our understanding of the phenomenon of the Irish 'church-building priest' in terms of their socio-economic background, fundraising abilities, and position within rural communities building on a new wave of research into the economic history of the Irish Catholic Church. ${ }^{4}$ Third, it focuses on the role that the Irish countryside played in conditioning clerical understandings of architectural style and taste, and in particular priests' political reading of the rural landscape. Fourth, it analyses the aesthetics of Marianism in church design and ornamentation around the time of the international 'Marian Year' of 1954. And finally, it focuses

\footnotetext{
${ }^{1}$ John A. O'Brien, The Vanishing Irish: The Enigma of the Modern World (London, 1954), p. 17.

2 R. F. Foster, Modern Ireland 1600-1972 (London, 1989), p. 535; Dermot Keogh, Finbarr O’Shea and Carmel Quinlan (eds), The Lost Decade: Ireland in the 1950s (Cork, 2004).

3 Desmond J. Keenan, The Catholic Church in Nineteenth-Century Ireland: A Sociological Study (Dublin, 1983), pp. 125-48; A. C. Smith, The South Ormsby Experiment: An Adventure in Friendship (London, 1960); Callum G. Brown, The Death of Christian Britain: Understanding Secularisation (2nd ed., Oxford, 2009); Denise Bonnette-Anderson, 'The Culture and Consequences of Anglican Church Redundancy, 1945-1995: Leicestershire and Lincolnshire' (PhD thesis, University of Leicester, 2020).

${ }^{4}$ Sarah Roddy, 'The Spoils of Spiritual Empire: Emigrant Contributions to Nineteenth-Century Irish Catholic Church Building', Journal of Irish and Scottish Studies, 5:2 (2012), pp. 95-116; Patrick Doyle and Sarah Roddy, 'Money, Death, and Agency in Catholic Ireland, 1850-1921', Journal of Social History (firstview online November 2019).
} 
on the political meanings of the rhetoric employed by Catholic clerics at church consecration ceremonies. Furthermore, the building of Dromore church is discussed here as the outcome of a conjunctural moment in Irish history, formed at the confluence of a range of local, national, and international events, both sacred and secular. This included a new bishop in the Cork \& Ross diocese, Cornelius Lucey (1902-1982), and his launching of an ambitious urban church-building programme in Cork city; the challenges and opportunities presented by rural emigration; the particular cultural imagination of a parish priest, formed by certain childhood experiences, socioeconomic factors, and geographies of the south-west of Ireland; and finally this priest's rural relocation of the eve of Pius XII's declaration of the Marian Year. ${ }^{5}$

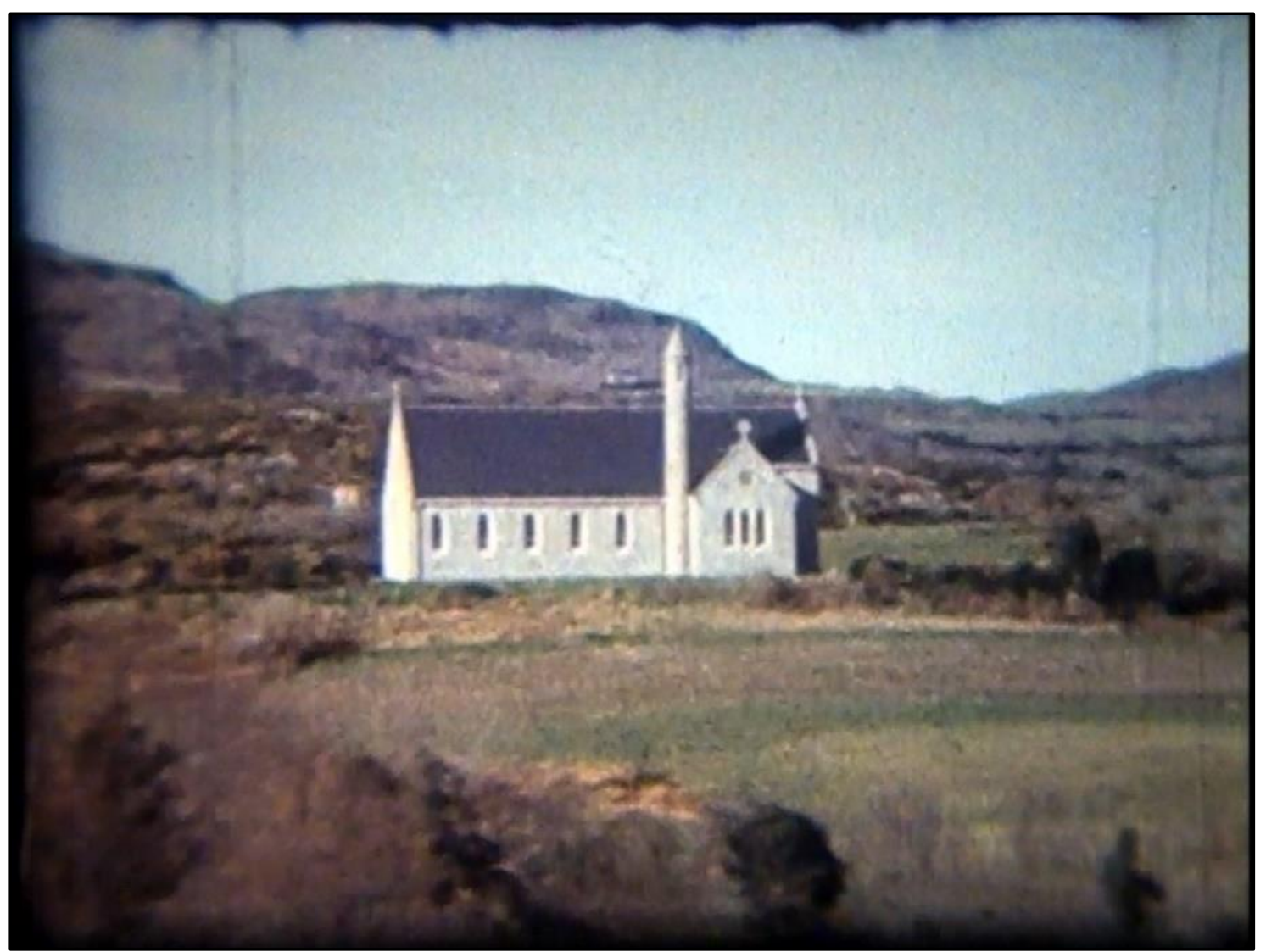

Fig. 1. The Church of Mary Immaculate, Dromore, Co. Cork, Ireland. A still from a video taken from a passing train by Walter McGrath, 1961. Reproduced courtesy of Michael Patterson.

\footnotetext{
${ }^{5}$ Anon., 'Our Lady's Year', The Furrow, 4:11 (1953), pp. 666-68; Robert A. Ventresca, Soldier of Christ: The Life of Pope Pius XII (Cambridge, MA., 2013), pp. 19, 39. For conjunctural history approaches, see Paul Pierson, Politics in Time: History, Institutions and Social Analysis (Princeton, NJ., 2004), p. 12; Shiv Visvanathan. 'Anna Hazare and the Battle against Corruption', Cultural Critique, 81 (Spring 2012), pp. 103111.
} 


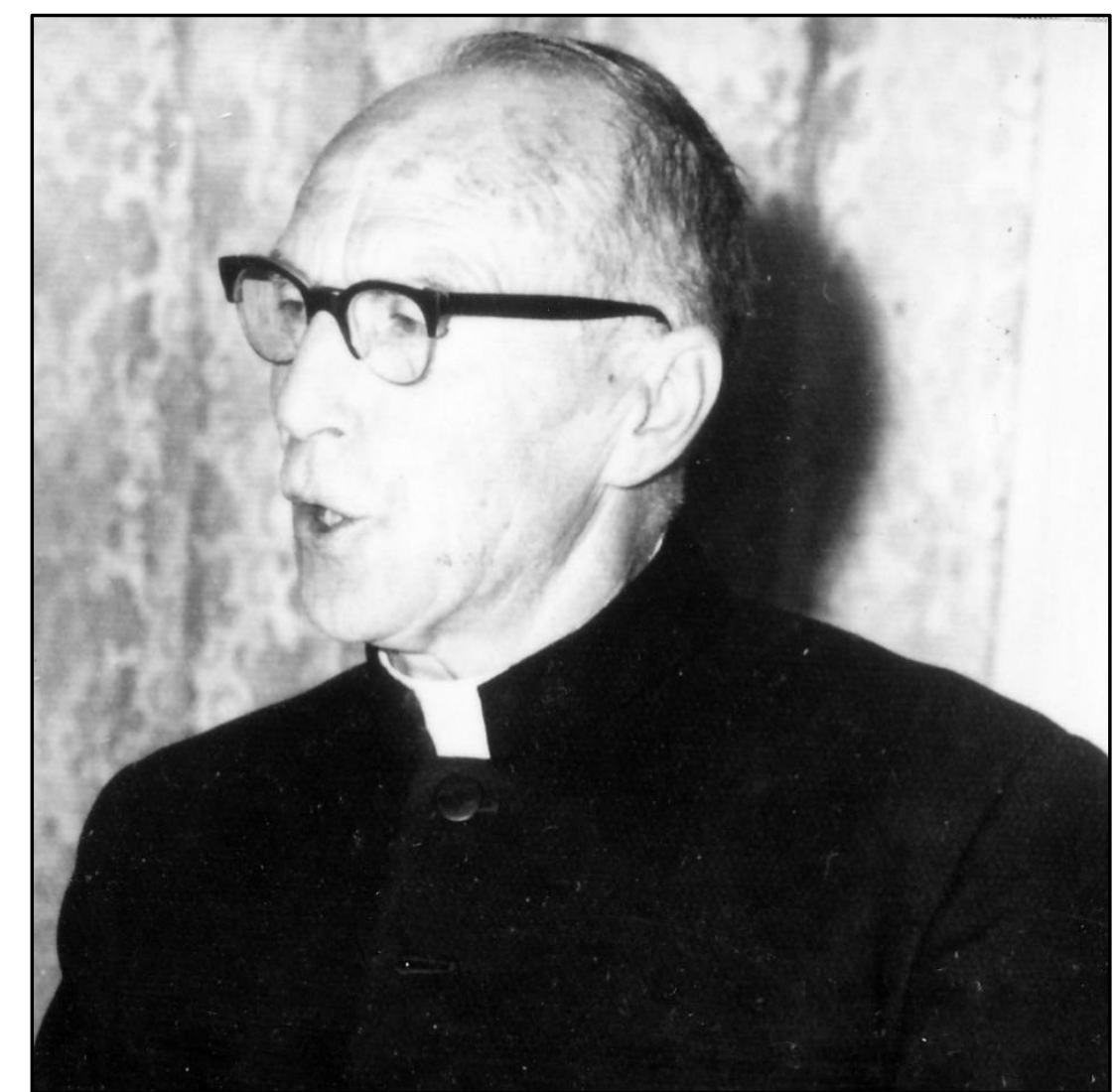

Fig. 2. Canon Patrick Henchy (1888-1969). Reproduced courtesy of Fr. Danny Pyburn, Dromore, and Mrs. Cecilia Wilcox, Dromore.

Considering the dominant role of religion in modern Irish culture, it is unsurprising that there is a very substantial literature on the twentieth-century history of the Irish Catholic Church. Early political surveys such as John Henry Whyte's Church and State in Modern Ireland (first published in 1971) have been followed in more recent years by a wealth of political, social and cultural studies, by James S. Donnelly, Lindsay Earner-Byrne and many others. ${ }^{6}$ The revelations of clerical institutional abuse since the 1990s have given impetus to a new wave of research into previously neglected aspects of the Irish post-war experience. Scholars including James Smith, Maria Luddy, Jacinta Prunty, Sarah-Anne Buckley, and others have brought into clear focus key questions of class, gender, and power within Irish Catholicism. ${ }^{7}$ Furthermore, sociological and

${ }^{6}$ John Henry Whyte, Church and State in Modern Ireland, 1923-1979 (1 st pub. 1971, revised Dublin, 1980); Dermot Keogh, The Vatican, the Bishops and Irish Politics, 1919-39 (Cambridge, 2004); John Cooney, John Charles McQuaid: Ruler of Catbolic Ireland (Dublin, 1999); James S. Donnelly Jr., 'The Peak of Marianism in Ireland, 1930-1960', in Stewart J. Brown and David W. Miller (eds), Piety and Power in Ireland, 1760-1960: Essays in Honour of Emmet Larkin (Notre Dame, IN, 2000), pp. 252-83; James S. Donnelly Jr., 'Opposing the "Modern World": The Cult of the Virgin Mary in Ireland, 1965-85', Eire-Ireland, 40:1-2

(Spring/Summer 2005), pp. 183-245; Lindsay Earner-Byrne, Mother and Child: Maternity and Child Welfare in Dublin, 1922-60 (Manchester, 2007); Lindsay Earner-Byrne, Letters of the Catholic Poor: Poverty in Independent Ireland, 1920-1940 (Cambridge, 2017); James S. Donnelly, Jr., 'Bishop Michael Browne of Galway (193776) and the Regulation of Public Morality', New Hibernia Review, 17:1 (2013), pp. 16-39; Daithí Ó Corráin, 'Catholicism in Ireland, 1880-2015: Rise, Ascendancy and Retreat', in Thomas Bartlett (ed.), The Cambridge history of Ireland: Volume IV: 1880 to the Present (Cambridge, 2018), pp. 726-64.

${ }^{7}$ James Smith, Ireland's Magdalen Laundries and the Nation's Architecture of Containment (Notre Dame, 2007); Maria Luddy, 'Unmarried Mothers in Ireland, 1880-1973', Women's History Review, 20:1 (2011), pp. 109126; Maeve O'Rourke, 'Ireland's Magdalene Laundries and the State's Duty to Protect', Hibernian Law 
anthropological studies, for example by Tom Inglis, Louise Fuller, and others have queried the relationships between the Catholic Church, politics and business in modern Ireland. ${ }^{8}$ They have unpacked the complexity of Irish religious experience and attempted to explore the reasons for its rapid decline in recent decades. 'These studies overlap with more general political, economic and cultural histories of post-war Ireland, with a dominant narrative throughout of emergence and enlightenment from a supposed insularity and stagnation (the 'lost' years of 'De Valera's Ireland' in the 1940s and 1950s) through to a sunburst of economic reforms and liberalisation from the late 1950s onwards, largely credited to the civil servant T. K. Whitaker. ${ }^{10}$

The 'lost decade' thesis, as Keogh terms it, is of course backed up by raw data: more than 400,000 people emigrated from Ireland during the 1950s, bringing the population down to its lowest-ever number of 2.8 million in 1961. Much of this exodus was from rural areas. ${ }^{11}$ Arguably the influential concept of a 'lost decade' has made the 1950s less attractive for new scholarly research - continuity presumably being less interesting than change. There are, however, many gaps within our knowledge of this key decade, not least in terms of some of the themes at the core of this article: rural culture, religion, and architectural production. ${ }^{12}$ Síle de Cléir's recent study of popular devotion in urban Limerick between the 1920s and the 1960s, based on oral history sources, has begun to shed more light on this important field of research. For Catholic church architecture, as de Cléir notes, the moment of change and renewal was not the economic reforms of the late 1950s but the profound devotional, cultural and material changes brought

Journal, 10 (2011), pp. 200-37; Jacinta Prunty, The Monasteries, Magdalen Asylums and Reformatory Schools of Our Lady of Charity in Ireland, 1853-1973 (Dublin, 2017); Sarah-Anne Buckley and Caroline McGregor, 'Interrogating Institutionalisation and Child Welfare: the Irish Case, 1939-1991', European Journal of Social Work, 22:6 (2019), pp. 1062-1072; Cara Delay and Annika Liger, 'Bad Mothers and Dirty Lousers: Representing Abortionists in Postindependence Ireland', Journal of Social History, (first-view online August 2019).

${ }^{8}$ Chris Eipper, The Ruling Trinity: A Community Study of Church, State and Business in Ireland (Aldershot, 1986). ${ }^{9}$ Tom Inglis, Moral Monopoly: The Catholic Church in Modern Irish Society (Dublin, 1987); Louise Fuller, Irish Catholicism since 1950: The Undoing of a Culture (Dublin, 2002); Louise Fuller, 'Catholicism in TwentiethCentury Ireland: From "an Atmosphere Steeped in the Faith" to a la carte Catholicism', Journal of Religion in Europe, 5:4 (2012), pp. 484-513; Callum Browne, Religion and the Demographic Revolution: Women and Secularisation in Canada, Ireland, UK and US A since the 1960s (London, 2012); Gladys Ganiel, Transforming Post-Catholic Ireland: Religious Practice in Late Modernity (Oxford, 2016); Síle de Cléir, Popular Catholicism in 20th-Century Ireland: Locality, Identity and Culture (London, 2017); Bruce Bradley (ed.), special issue of Studies: An Irish Quarterly Review, on 'The Future of Irish Catholicism', 106:421 (Spring 2017), pp. 3-94.

${ }^{10}$ Tom Garvin, Preventing the Future: Why was Ireland so Poor for so Long? (Dublin, 2004); Diarmaid Ferriter, The Transformation of Ireland, 1900-2000 (London, 2004), pp. 23-24 and 465-70; Tom Garvin, News from a New Republic: Ireland in the 1950s (Dublin, 2010); Anne Chambers, T. K. Whitaker: Portrait of a Patriot (Dublin, 2014); Mary E. Daly, Sixties Ireland: Reshaping the Economy, State and Society, 1957-1973 (Cambridge, 2016); Brian Girvin, 'Stability, Crisis and Change in Post-War Ireland, 1945-1973', in Bartlett, The Cambridge History of Ireland: Volume IV: 1880 to the Present, pp. 381-406.

${ }^{11}$ Dermot Keogh, 'Introduction: The Vanishing Irish', and Gerry O'Hanlon, 'Population Change in the 1950s: A Statistical Review', in Keogh et al., The Lost Decade, pp. 11-20 and pp. 72-79; Foster, Modern Ireland, p. 578; Census of Population of Ireland, 1961: Volume 1: Population, Area and Valuation of each District Electoral Division and of each larger Unit of Area (Dublin, 1963).

${ }^{12}$ John A. Murphy, 'Lost Decades?' (review), The Irish Review, 33 (Spring 2005), pp. 134-36; Erika Hanna, Modern Dublin: Urban Change and the Irish Past, 1957-1973 (Oxford, 2013), pp. 55-56; Ellen Rowley, 'Surrealist Structures: The Culture of Architecture in 1940s and 1950s Ireland', The Irish Review, 51 (2015), pp. 47-66; Eleanor O'Leary, Youth and Popular Culture in 1950s Ireland (London, 2018); Richard J. Butler, 'Catholic Power and the Irish City: Modernity, Religion, and Planning in Galway, 1944-49', Journal of British Studies, (forthcoming July 2020). 
about a decade later by 'Vatican II'. ${ }^{13}$ Irish Catholic church architecture of the 1940s and 1950s remains largely neglected, despite the pioneering work of Ellen Rowley and others. ${ }^{14}$ Considering the sheer number of new churches built mid-century, it is remarkable how few have been studied in any detail. Scholarly analysis continues to be substituted by journalistic invective, as for example in Brian Fallon's view from the late 1990s: Irish Catholic priests, were, he argued

'for the most part, very ordinary men (very often younger sons of farmers) without original ideas or judgement, and untrained in any method of constructive criticism something which would certainly not have been encouraged officially, in any case.... Culturally the clergy were mostly philistines, as was immediately obvious from the ugliness of many or most of the parish churches'. ${ }^{15}$

In exploring the building of a church in rural west Cork, this article uses new archival evidence to offer a more nuanced perspective on mid-century Catholic clerics and their architectural and material culture. It shows how a parish priest engaged in a serious and scholarly way with architectural style and how he weaved together rural religious tradition with a profound admiration for the mountainous landscape of the south-west of Ireland. The article follows in the wake of earlier research on the nineteenth century by Larkin, David W. Miller and Kevin Whelan, and more recent interventions by Cara Delay, Sarah Roddy and many others, in attempting to understand the materiality of the Irish Catholic Church in its socio-economic and cultural contexts. ${ }^{16}$ The building of Dromore church is a particularly rewarding case-study for

${ }^{13}$ Richard Hurley and Wilfrid Cantwell (eds), Contemporary Irish Church Architecture (Dublin, 1985), pp. 3568; Fuller, Irish Catholicism since 1950, pp. 111-16; Robert Proctor, Building the Modern Church: Roman Catholic Church Architecture in Britain, 1955 to 1975 (Farnham, 2014); de Cléir, Popular Catholicism in 20th-Century Ireland, pp. 2-15; Ellen Rowley, 'Andrew Devane's Dublin Churches: Catholic Architecture in Ireland in an Age of Tentative Radicalization, 1960-1975', in Lisa Godson and Kathleen James-Chakraborty (eds), Modern Religious Architecture in Germany, Ireland and Beyond: Influence, Process and Afterlife since 1945 (London, 2019), pp. 62-86.

${ }^{14}$ Fuller, Irish Catholicism since 1950, pp. xxv, 22, 91-92; Ellen Rowley, 'Transitional Modernism: the Case of 1950s Church Architecture in Dublin', in Edwina Keown and Carol Taffe (eds), Irish Modernism: Origins, Contexts, Publics (London, 2009), pp. 195-216; Ellen Rowley, 'Catholic Churches and Cathedrals in the Twentieth Century', in Andrew Carpenter, et al. (eds), Art and Architecture of Ireland: Volume IV: Architecture, 1600-2000 (Dublin, New Haven and London, 2014), pp. 295-99; Richard J. Butler, 'All Saints, Drimoleague, and Catholic Visual Culture under Bishop Cornelius Lucey in Cork, 1952-9', Journal of the Cork. Historical and Archaeological Society, 120 (2015), pp. 79-97; Antoin O'Callaghan, The Churches of Cork City: An Illustrated History (Dublin, 2016); Paula Murphy, 'Art and Architecture in Ireland, 1880-2016', in Bartlett, The Cambridge History of Ireland: Volume IV: 1880 to the Present, pp. 765-808, at pp. 788-89.

15 Brian Fallon, An Age of Innocence: Irish Culture, 1930-1960 (New York, 1998), p. 190. For a corrective, see Alan A. Gillis, 'Not so Innocent' (review), The Irish Review, 26 (Autumn 2000), pp. 143-45. For similar views from the 1950s and 1960s, see Anon., 'Church Architecture Symposium', Irish Builder and Engineer, 97:10 (7th May 1955), pp. 461-62 and Ian Nairn, 'Ecclesiastical All-Sorts', The Observer, 24th April 1966. 16 Thomas P. Kennedy, 'Church Building', in P. J. Corish (ed.), A History of Irish Catholicism, Vol. 5: The Church since Emancipation (Dublin, 1970), pp. 1-36; Keenan, The Catholic Church in Nineteenth-Century Ireland, pp. 125-48; Kevin Whelan, 'The Catholic Parish, the Catholic chapel, and Village Development in Ireland', Irish Geography, 16 (1983), pp. 1-15; David W. Miller, 'Landscape and Religious Practice: A Study of Mass Attendance in Pre-Famine Ireland', Éire-Ireland, 40:1-2 (Spring-Summer, 2005), pp. 90-106; Emmet Larkin, The Pastoral Role of the Roman Catholic Church in Pre-Famine Ireland, 1750-1850 (Dublin and Washington, D.C., 2006), pp. 137-88; Brendan Grimes, 'Funding a Roman Catholic Church in Nineteenth-Century Ireland”, Architectural History, 52 (2009), pp. 147-68; Cara Delay, “'The Gates Were Shut": Catholics, Chapels, and Power in Late Nineteenth Century Ireland', New Hibernia Review, 14:1 (2010), pp. 14-35; Cara Delay, “Language Which Will Move Their Hearts”: Speaking Power, Performance, and the Lay-Clerical Relationship in Modern Catholic Ireland', Journal of British Studies, 53:2 (2014), pp. 426-52; Roddy, 'The Spoils of Spiritual Empire'; Doyle and Roddy, 'Money, Death, and 
four key reasons: first, it occurred at the very high-water mark of popular and official Catholic devotion in Ireland around the Marian Year of 1954, before the Church began to go into decline (in ordinations, and later in mass attendance, cultural esteem and political influence). ${ }^{17}$ Second, it occurred within the diocese of Cork \& Ross, which was led from 1952 until 1980 by Lucey, one of Ireland's most influential and outspoken clerical sociologists. ${ }^{18}$ Lucey regularly spoke and wrote about issues such as emigration, rural life, Marianism, and family values, yet remains largely neglected in existing scholarship. ${ }^{19}$ He oversaw one of the most ambitious programmes of church building outside of Dublin: between 1953 and 1963, he built 10 new churches in the diocese: 7 in or near Cork city and 3 clustered together in west Cork. ${ }^{20}$ This article adds to our admittedly limited - understanding of the early years of Lucey's tenure as bishop. Third, the building of Dromore church occurred in a county of Ireland - Cork - that is richly served in existing eighteenth- and nineteenth-century socio-economic histories by David Dickson and Donnelly (for whom County Cork had 'some claim to be regarded as a microcosm of the entire country'), and in more recent work by Eipper, Peter Hart, and others. ${ }^{21}$ Eipper, who undertook anthropological research near Dromore in the 1970s, was moved by the 'pervasive catholicity' of the people he studied. He found religious expression in their 'sentiments expressed in the media, literature [,] song [and] in the very idioms of [their] language', and suggested that 'people keenly appreciated the fact that, compared with ... other countries, religion occupied a distinctive place in their life. ${ }^{.22}$ And finally, the building of Dromore church is unusually well documented in both visual and textual archives. Henchy wrote regularly for the diocesan magazine, The Fold, founded by Lucey in 1953, and for the local newspaper, the Southern Star. Few other church-building projects in 1950s Ireland are so well served by surviving historical sources. For example, less than eight kilometres from Dromore, another new church was built at the same time; however, far fewer sources survive and the parish priest responsible remains a much more elusive figure. ${ }^{23}$ Methodologically, this article analyses a substantial body of written and visual sources that survive but also pieces together Henchy's family background and career using biographical records from the Cork \& Ross diocese and socio-economic data from the digitised Irish census returns.

Agency in Catholic Ireland'; Stuart Henderson, 'Religion and Development in Post-Famine Ireland', The Economic History Review, 72:4 (2019), pp. 1251-85.

${ }^{17}$ Brian Conway, 'Contexts of Trends in the Catholic Church's Male Workforce: Chile, Ireland, and Poland Compared', Social Science History, 40:3 (2016), pp. 405-32, at pp. 417-19.

18 Paul Blanshard, The Irish and Catholic Power: An American Interpretation (London, 1954), pp. 41, 74-75, 192, 200; Michael Sheehy, Is Ireland Dying? Culture and the Church in Modern Ireland (London, 1968), pp. 184-98;

Whyte, Church and State in Modern Ireland, pp. 196-272; Fuller, Irish Catholicism since 1950, pp. xvii, 45-47, 75, 78-79, 138, 230.

${ }^{19}$ Sheehy, Is Ireland Dying?, pp. 184-98; Ferriter, Transformation of Ireland, p. 12; Butler, 'All Saints, Drimoleague, and Catholic Visual Culture under Bishop Cornelius Lucey', pp. 80-85; Richard J. Butler, 'All Saints, Drimoleague: Clarifications and new Discoveries', Journal of the Cork. Historical and Archaeological Society, 121 (2016), pp. 141-43.

${ }^{20}$ Cork Evening Echo, 30th May 1953; Anon., 'The Great Ten Years in Caheragh', The Fold, June 1963, pp. 27-30. The west Cork churches are Dromore, Drimoleague, and Caheragh - see Butler, 'All Saints, Drimoleague, and Catholic Visual Culture under Bishop Cornelius Lucey'. For the city churches, see Richard J. Butler, Town Planning and the Catholic Church in Cork and Waterford cities, 1935-1965, in preparation. ${ }^{21}$ James S. Donnelly, Jr., The Land and the People of Nineteenth-Century Cork: The Rural Economy and the Land Question (London, 1975), p. 2; Eipper, The Ruling Trinity; Peter Hart, The I.R.A. and Its Enemies: Violence and Community in Cork, 1916-1923 (Oxford, 1998); David Dickson, Old World Colony: Cork and South Munster, 1630-1830 (Cork and Madison, WI., 2005); David Butler and Joseph Ruane, 'Identity, Difference and Community in Southern Irish Protestantism: The Protestants of West Cork', National Identities, 11:1 (2009), pp. 73-86.

22 Eipper, The Ruling Trinity, pp. 93-94.

${ }^{23}$ Butler, 'All Saints, Drimoleague, and Catholic Visual Culture under Bishop Cornelius Lucey'. 


\section{0s mentalities: Catholic cultural nationalism}

The 1950s marked the peak of triumphant Catholic cultural nationalism in Ireland, and this mentality was deeply rooted both in the canonical texts of early twentieth-century cultural nationalism more broadly and in an understanding of the Irish rural landscape. The two were, of course, linked: Daniel Corkery's The Hidden Ireland: a study of Gaelic Munster in the eighteenth century (1924) situated Gaelic (and thereby Catholic) 'Irish Ireland' away from the cities and towns, 'among the bogs and hills', he suggested, and 'far into the mountains'. This was where, he thought, 'the native Irish ... still lurked', with what Corkery saw as their purer culture, language, and religion. ${ }^{24}$ The creation of the Irish Free State in the 1920s, with its remarkably homogeneous Catholic populace, marked a triumph for the institutional Church and, in the decades that followed, Church and state worked largely in tandem to reinforce a particular form of socially and economically conservative Catholicism. The Church also emphasized the religious devotion of many nationalist leaders, thereby recasting the revolution itself as a 'Catholic' uprising. The close relationship between Church and state was evident, for example, in the celebration of the centenary of Catholic Emancipation in 1929; the hosting of the International Eucharistic Congress in Dublin in 1932; in new legislation governing sexuality, family life and censorship; and in the drafting of the 1937 Irish Constitution. ${ }^{25}$

Henchy's writings during his time as parish priest of Caheragh, and in some later reflections, show a deep understanding of these interwoven aspects of Irish cultural nationalism. Born into 'a well-known Cork City family' in 1888, and ordained in 1913, his early years teaching in the diocesan seminary at Farranferris in Cork city were punctuated by the War of Independence (1919-21), the burning of Cork city by British forces (1920), and the Civil War (1922-23). ${ }^{26}$ His petit bourgeois father John, whom he referred to throughout his life as 'the boss', owned a large pub at St. Luke's Cross in the north inner city, close to a substantial military barracks. ${ }^{27}$ The youngest son from a family of five boys and a girl, Henchy grew up in what the 1901 census referred to as a ' $1{ }^{\text {st }}$ class' house, and like many sons of the comfortable Irish Catholic 'shopocracy', he made a distinguished career in the priesthood. ${ }^{28} \mathrm{He}$ was asked to serve as diocesan inspector of schools in the late 1920s. Touring the countryside with the privilege of

${ }^{24}$ Daniel Corkery, The Hidden Ireland: A Study of Gaelic Munster in the Eighteenth Century (1 ${ }^{\text {st }}$ pub. 1924, Dublin, 1967), pp. 19-20; D. P. Moran, The Philosophy of Irish Ireland (Dublin, 1905), pp. 112-13. See also L. M. Cullen, 'The Hidden Ireland: Re-Assessment of a Concept', Studia Hibernica, 9 (1969), pp. 7-47, at pp. 10-11; John Hutchinson, The Dynamics of Cultural Nationalism: The Gaelic Revival and the Creation of the Irish Nation State (Boston, 1987); Heather Laird, 'Introduction: Daniel Corkery as Postcolonial Critic', in Heather Laird (ed.), Daniel Corkery's Cultural Criticism (Cork, 2012), pp. 1-14.

25 Whyte, Church and State, pp. 24-119; Keogh, The Vatican, the Bishops and Irish Politics, pp. 123-220; R. F. Foster, Vivid Faces: The Revolutionary Generation in Ireland, 1890-1923 (London, 2014), pp. 289-326; Ó Corráin, 'Catholicism in Ireland', pp. 729-39.

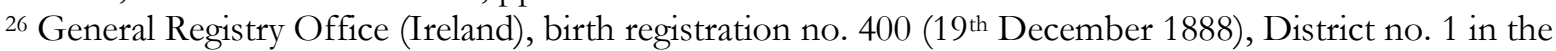
Union of Cork in the County of City of Cork, p. 83 (https://www.irishgenealogy.ie) [accessed $8^{\text {th }}$ January 2020]; Southern Star, 7th November 1953; Cork and Ross Diocese biographical records, 'Very Rev. Canon Patrick Henchy PP', (http://corkandross.org/priests/very-rev-canon-patrick-henchy-pp-2) [access $8^{\text {th }}$ January 2020]. 271901 Census for house 2, Rathmore, North East Ward, Cork (http://www.census.nationalarchives.ie) [accessed 8th January 2020]; Guy's City and County Almanac and Directory for 1945 [Cork], p. 221 (http:/ / www.corkpastandpresent.ie) [accessed 8th January 2020]; Patrick Henchy, 'Fifty Years a Priest', The Fold, July 1963, pp. 15-18, at pp. 15-16.

${ }^{28}$ Henchy, 'Fifty Years a Priest', pp. 15-16; Southern Star, 19th April 1969. For 'shopocracy', see David Dickson, Dublin: The Making of a Capital City (London, 2014), pp. 336-40. 
access to a car gave him an opportunity to escape the city and appreciate the coastal and mountainous scenery of the western reaches of the diocese. As he recalled in 1963, 'I was on the run .... Four years spent travelling with the Catechism gave me an insight into the topography of the diocese of Cork. [It] was hard but pleasant going and showed me the kindness and understanding of the priests and teachers. ${ }^{29}$ Urban life then returned and between the 1930s and the early 1950s he served as curate (CC) of the poor inner-city parish of SS. Peter \& Paul's. It was, he remembered somewhat bleakly, 'smoke and lanes ..., miles of stairs and countless cases. It took a lot of getting used to, but gradually the humour and goodness of the poor cut one down to size and working in the slums became real happiness'. ${ }^{30}$ Then, in October 1953, shortly after the beginning of Lucey's tenure as bishop, he had another chance to escape urban life with a promotion to parish priest (PP) at the age of 64 and a move to Caheragh in west Cork. ${ }^{31}$ This parish, entirely rural, was made up of a church in Caheragh (sometimes known as Killeenleigh) and a chapel-of-ease in nearby Dromore (Fig. 3). The relocation had a great effect and marked a new chapter in his life. More broadly, anti-urbanism was commonplace within Irish Catholic mentalities at the time (for example in the handbooks of the rural community development organisation Muintir na Tíre), with the countryside, as in other countries, seen as a reservoir of social virtue and moral probity. ${ }^{32}$ For Henchy, set free from the city after 18 years, the move had immediate practical consequences: 'I shaved', he said, 'with an electric razor on Saturday morning in [Cork]; on Sunday, in Caheragh, I had to manage with a basin of cold water, a cutthroat, and with the light of a candle'. The old parish church, from the 1820s, 'had no pulpit'. He was endeared by what he saw as the uncomplicated life of the rural community, into whose world he now entered. In the church, 'the people were all around. It was very different from talking from the raised, carved, commanding pulpit in SS. Peter and Paul's.' 'It was', he thought with little attempt to conceal a patrician tone, 'like teaching in a classroom of very attentive pupils. ${ }^{33}$

Henchy was greatly affected by what he perceived as the humble piety of the rural people and situated this within a broader narrative of triumphant Catholic cultural nationalism. Soon after his arrival in Caheragh, he wrote a short essay for the diocesan magazine The Fold about a 'Holy Year' cross built on top of a hill in the parish (Fig. 4). In response to Pius XII's declaration in 1950 of a Holy Year for the Church, 45 men volunteered to build a 25-feet-high concrete cross on the rocky outcrop behind Dromore's early nineteenth-century chapel-of-ease. ${ }^{34}$ The cross was one of the many visual signifiers of Catholicism in the Irish countryside including churches, shrines, and grottos. Henchy understood it as an act of 'from below' popular devotion but also as a territorial claim on the Irish landscape in Corkery's 'hidden Ireland'. Irish hills had long been appropriated for military, political and religious purposes. Following the failed French invasion of 1796, signal and Martello towers were built by the British state along the coastline; many of these, especially in the south-west, survive as ruins on promontories and

\footnotetext{
${ }^{29}$ Henchy, 'Fifty Years a Priest', p. 16; Cork and Ross Diocese biographical records.

30 Southern Star, $7^{\text {th }}$ November 1953; Henchy, 'Fifty Years a Priest', p. 17.

31 Promotion to PP at such a senior age was not unusual in 1950s Ireland with such a large body of serving priests - see Conway, 'Contexts of Trends in the Catholic Church's Male Workforce', pp. 416-19. 32 John Hayes, 'The Beginning', Muintir na Tíre Official Handbook, 1941 (Dublin, 1941), pp. 43-50. See also Liam O'Dowd, 'Town and Country in Irish Ideology', The Canadian Journal of Irish Studies, 13:2 (1987), pp. 43-53, at pp. 46-48; Mervyn Horgan, 'Anti-Urbanism as a Way of Life: Disdain for Dublin in the Nationalist Imaginary', Canadian Journal of Irish Studies, $30: 2$ (Fall 2004), pp. 38-47, at p. 38.

33 Henchy, 'Fifty Years a Priest', p. 17.

${ }^{34}$ Luigi Guinta, The Holy Year: History, Doctrine, Liturgy (Vatican City, 1950), pp. 117-21; Southern Star, $18^{\text {th }}$ November 1950; Siobhán Holland, A History of Caheragh Parish (Bantry, n.d. [c. 2000]), p. 20; Donal J. O’Sullivan and Cammy Harley, The History of Caheragh Parish (Skibbereen, 2010), pp. 83-90, 179-80.
} 
hill tops. ${ }^{35}$ In the nineteenth century, bonfires were lit on hills to endorse secret society activity and mark major nationalist political meetings. ${ }^{36}$ Well into the twentieth century, festivals such as Beltane (in May) and Saint John's Eve (in June) were accompanied by hill bonfires. ${ }^{37}$ Henchy's story centres on a devout married man 'with an incurable malady' who lived in the shadow of the new cross on Dromore hill. When, Henchy 'first saw the Holy Year Cross on the hill of Dromore', he thought it looked like 'a flag floating over a besieged fortress', a 'stronghold [that] would never be taken'. 'The flag', he added, 'would ever float victoriously'. He was moved by the barrenness of the landscape, commenting that 'there is something fascinating about hills.... the bare rocky heights showing their strength in naked stone'. Yet the tragedy of the man's illness cast a dark shadow on the landscape, and in emotive language, Henchy commented that 'it is a shocking thing to see a man crying'. The story then takes a dramatic turn as the man spots the cross on the hill, and reinvigorated by his faith, straightens 'his withered frame' and squares 'his thin shoulders'. Triumphantly recalling the death of Jesus on the cross, the man turns to the priest and says, 'he conquered death and with God's help I and mine will too'. For Henchy, this experience was an opportunity to reflect on, as he put it, 'the splendour of the high hills and the greatness of the souls of the men who were born and who lived amongst them'. 'The hearts of the men of the hills', as he described his parishioners, were inseparable from the triumph of the Church itself through the visual signifier of the Holy Year cross. Demonstrating his deep romantic appreciation for the Irish rural landscape, his essay set the tone for his extensive writings in the diocesan magazine and in the local newspaper during the building of Dromore church. $^{38}$

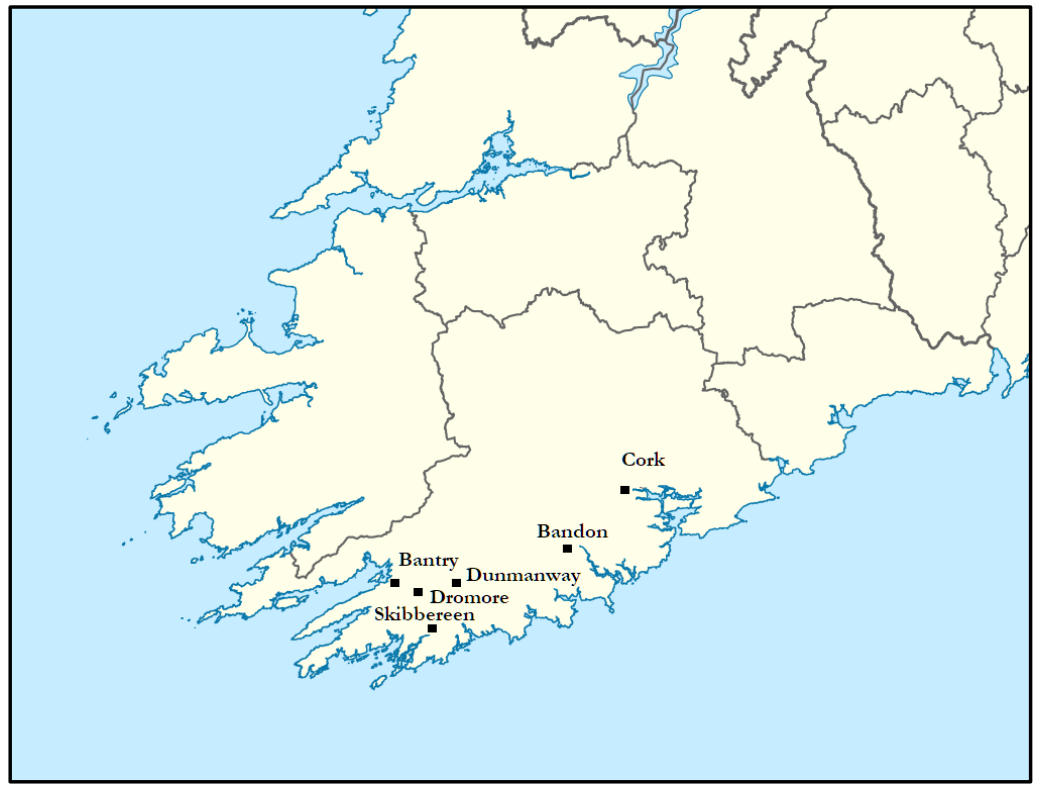

Fig. 3. The south-west of Ireland, showing relevant settlements in County Cork.

\footnotetext{
35 Paul M. Kerrigan, Castles and Fortifications in Ireland, $1485-1945$ (Cork, 1995), pp. 150-247; Evan Wilson, 'The Naval Defence of Ireland during the French Revolutionary and Napoleonic Wars', Historical Research, 92:257 (August 2019), pp. 568-84.

36 Freeman's Journal, 2nd October 1843; Anon., 'Ireland', Western Literary Messenger (Buffalo, New York), 9:23 (8th January 1848), pp. 366-67.

${ }^{37}$ Alan Gailey and G. B. Adams, 'The Bonfire in North Irish Tradition', Folklore, 88:1 (1977), pp. 3-38, at p. 7; Patricia O'Hare, 'St. John's Eve Traditions in County Kerry, c. 1850-1950', Béaloideas, 76 (2008), pp. 23-88, at pp. 27-28. See also de Cléir, Popular Catholicism in 20th-Century Ireland, pp. 78-85.

${ }^{38}$ Patrick Henchy, 'The Cross on the Hill', The Fold, June 1954, pp. 22-23. This melodramatic form of writing was very common at the time, and Henchy's tone would not have stood out as overly romantic or emotive - see for another example Southern Star, $9^{\text {th }}$ April 1955.
} 




Fig. 4. Dromore church with the 'Holy Year' cross, built in 1950, on the hill behind.

Photograph by author, 2016.

\section{The church-building priest}

The process of building or reconstructing a church was both a spiritual and a practical concern. ${ }^{39}$ For some priests, engaging in fundraising, planning and construction came rather naturally, and in Ireland and probably many other countries, we find the phenomenon of the 'church-building priest'. These men often came from comfortable, middle-class backgrounds and had the social and cultural capital to organise a community and raise the finances to undertake building work. They might otherwise quite easily have become involved in business, construction, or engineering, but as priests they were almost continually involved in some kind of construction.

39 There are numerous scriptural references to the construction of temples as metaphors for Christ and the Christian community - see for example Matthew 21:42, Mark 12:10, 1 Peter 2:5-7, 1 Corinthians 6:19, etc.; and the writings of St. Francis of Assisi. See also anon., 'Laying the Foundation Stone', The Fold, 2:2 (August 1954), pp. 21-22; Theodor Klauser, 'Directives for Building a Church', The Furrow, 6:6 (June 1955), pp. 372-80; and A. G. Martimort, The Church at Prayer: An Introduction to the Liturgy (New York, 1968), pp. 166-67. I am grateful to Fr. Fintan Lyons and Dr. Sarah Goldsmith for several of these references. 
In general, they were shaped by certain childhood experiences and tended to follow similar rolemodels. In coordinating the different phases of architectural production, they fell easily into highly gendered, bourgeois categories of respectability, 'hard work' and 'common sense' - the product again of certain forms of family background and education. ${ }^{40}$ Recent research has highlighted the economic importance of parish priests in modern Irish history, though examples from the post-war years are relatively scarce. ${ }^{41}$ For example, in Donegal in the 1850 s, the priest Edward Glacken is described by Brendán Mac Suibhne as politically active in his local Repeal campaign and as a 'consummate organizer' who had overseen the building of a new chapel and schools in his parish. ${ }^{42}$ And in east County Galway in the 1930s, the priest Malachy Brennan built two churches, two parish halls, six schools, a priest's house and a handball alley in the space of ten years. A Gaelic Leaguer, he had combined his pastoral work with the founding of a Sinn Féin branch and had given many nationalist sermons from the pulpit. His building work was, the Connacht Tribune commented, the result of his 'organising genius' and the 'esteem in which [he was] held'. ${ }^{43}$ Henchy was similarly a classic church-building priest. In almost all his appointments as PP, he undertook some building work. ${ }^{44}$ Within a month of moving to Caheragh, he announced plans for building the new chapel-of-ease in Dromore. At the same time, Lucey was beginning work on five large new churches in Cork city, and while this placed a huge financial burden on the diocese as a whole (around $f_{500,000)}$, Lucey extended an offer of some support to the Caheragh parish. ${ }^{45}$ He endorsed the rebuilding plans in a letter that Henchy read to his parishioners in December 1953. The old church, Lucey wrote, was 'in very bad condition, so bad in fact that to put it in good order would cost practically as much as to replace it with a new one'. Reflecting the commencement of the Marian Year on the feast-day of the Immaculate Conception, he suggested the new church, which might cost $f 15,000$, could be dedicated to Mary: 'a special Mass will be offered in it every year ... on the Feast of Our Lady,' he promised, 'for benefactors living and dead." 46

While the sum to be raised in Caheragh was small compared to Lucey's plans for the city, it was nonetheless a formidable hurdle for a rural community that had been greatly affected by high levels of emigration - in the post-Famine years but also through the twentieth century. ${ }^{47}$ In these years the total parish collection each year amounted to around $f 700-$ from which the

\footnotetext{
${ }^{40}$ Ciaran O'Neill, 'Bourgeois Ireland, or, on the Benefits of Keeping One's Hands Clean', in James Kelly (ed.), The Cambridge History of Ireland: Volume III, 1730-1880 (Cambridge, 2018), pp. 517-41; Mary Hatfield, Growing Up in Nineteenth-Century Ireland: A Cultural History of Middle-Class Childhood and Gender (Oxford, 2019), chapter 5.

${ }^{41}$ Grimes, 'Funding a Roman Catholic Church'; Delay, “Language Which Will Move Their Hearts”, p. 426; Roddy, 'The Spoils of Spiritual Empire'; Doyle and Roddy, 'Money, Death, and Agency in Catholic Ireland'; Sarah Roddy, Money and Irish Catholicism, 1850-1921, in preparation.

${ }^{42}$ Brendán Mac Suibhne, The End of Outrage: Post-Famine Adjustment in Rural Ireland (Oxford, 2017), pp. 182-83.

${ }^{43}$ Connacht Tribune, 17th June 1939; Marty Gilmore and Mattie Kilroy, The History of Ahascragh \& Caltra (Ballinasloe, 1993), pp. 146-47, 189; Richard J. Butler, 'Notes on the Art and Architecture of East Galway in the Vicinity of Ahascragh', Journal of the Galway Archaeological and Historical Society, 70 (2018), pp. 35-51, at p. 36.

${ }^{44}$ For later building work, see for example his involvement in the rebuilding of Crosshaven church in the 1960s - Patrick Henchy, 'Crosshaven by the Sea', The Fold, January 1960, pp. 32-34; Irish Builder and Engineer, 102 (23 'd July 1960), p. 551; Henchy, 'Fifty Years a Priest', pp. 17-18.

45 Southern Star, $5^{\text {th }}$ September 1953.

46 Southern Star, 12th December 1953.

${ }^{47}$ David R. Stead, 'Economic Change in South-West Ireland, 1960-2009', Rural History, 22:1 (2011), pp. 115-46, at pp. 116-22.
} 
priest and curate's salaries were paid. ${ }^{48}$ The pressure that the church-building campaign placed on the community is evident in a detailed examination of census returns. Though there is, as Eoin O'Mahony has shown, significant variation between Irish parish and census boundaries, changes in the Caheragh parish can be represented with reasonable accuracy by studying the returns for the two District Electoral Divisions (DEDs) of Gortnascreeny (for the north of the parish) and Caheragh (for the south). ${ }^{49}$ By the early 1950s, the area's population had reduced by one-third since 1911, and this increased further to almost one-half of its 1911 level by 1966 (Fig. 5). Though the two nearby towns of Skibbereen and Bantry also saw significant depopulation, this was less pronounced than in their rural hinterland, and they began to experience a reversal of fortunes from the early 1960s. In absolute numbers, the Catholic population of the parish fell from around 2,500 persons to just 1,750 in the years between Henchy's tenure as schools' inspector in the 1920s and his return as PP in the 1950s. ${ }^{50}$ The Southern Star sounded alarm in these years with the headline, 'Population at Lowest Point Ever: Emigration Toll'. ${ }^{51}$ In terms of taxable valuation, the Caheragh area lagged far behind its nearby towns, especially from the 1950s onwards (Fig. 6)..$^{52}$ As this data is unadjusted for inflation, it is clear that the area's valuation decreased significantly in real terms in the years after independence. ${ }^{53}$ Overall these figures show just how daunting was Henchy's building campaign. Yet emigration brought an unexpected bonus when a site for the new church was donated by a local man, whose brother, the Southern Star noted, served as a priest in 'the oil-producing state of Oklahoma'. ${ }^{54}$ As Roddy has shown, Irish Catholics abroad often played an important role in helping the Church back at home. ${ }^{55}$

\footnotetext{
48 Annual statement of parish accounts for Caheragh, 1953, 1954, 1956 and 1957 (Cork and Ross Diocesan Archive, Caheragh parish reports (254/11C)).

${ }^{49}$ Eoin O'Mahony, 'Problems with Drawing Lines: Theo-Geographies of the Catholic Parish in Ireland', Journal of the Irish Society for the Academic Study of Religions, 1:1 (2014), pp. 48-65. Gortnascreeny (Cork Rural DED no. 309) contained 14 townlands; Caheragh (Cork Rural DED no. 303) contained 13 townlands. The boundaries of both these DEDs did not change during the period under scrutiny.

${ }^{50}$ Diocese of Cork visitation queries, parish of Caheragh, 1953 (Cork and Ross Diocesan Archive, Caheragh parish reports $(254 / 11 \mathrm{C}))$.

51 Southern Star, 9th June 1956.

52 Saorstát Éireann: Census of Population, 1926: Volume 1: Population, Area and V aluation of each District Electoral Division and of each larger Unit of Area (Dublin, 1928), pp. 81-91; Ireland: Census of Population, 1936: Volume 1: Population, Area and V aluation of each District Electoral Division and of each larger Unit of Area (Dublin, 1938), pp. 81-90; Census of Population of Ireland, 1946: Volume 1: Population, Area and V aluation of each District Electoral Division and of each larger Unit of Area (Dublin, 1949), pp. 81-90; Census of Population of Ireland, 1951: Volume 1: Population, Area and Valuation of each District Electoral Division and of each larger Unit of Area (Dublin, 1952), pp. 89-110; Census of Population of Ireland, 1956: Population, Area and Valuation of each District Electoral Division and of each larger Unit of Area (Dublin, 1957), pp. 86-95; Census of Population of Ireland, 1961: Volume 1:

Population, Area and V aluation of each District Electoral Division and of each larger Unit of Area (Dublin, 1963), pp. 88-97; Census of Population of Ireland, 1966: Volume 1: Population of District Electoral Divisions, Towns and larger Units of Area (Dublin, 1967), pp. 109-115.

${ }^{53}$ Central Statistics Office (Ireland), Consumer Price Index Base, 1922-2019 (www.cso.ie) [accessed 9th January 2020].

54 Southern Star, 30th January 1954.

${ }^{55}$ Roddy, 'The Spoils of Spiritual Empire’.
} 


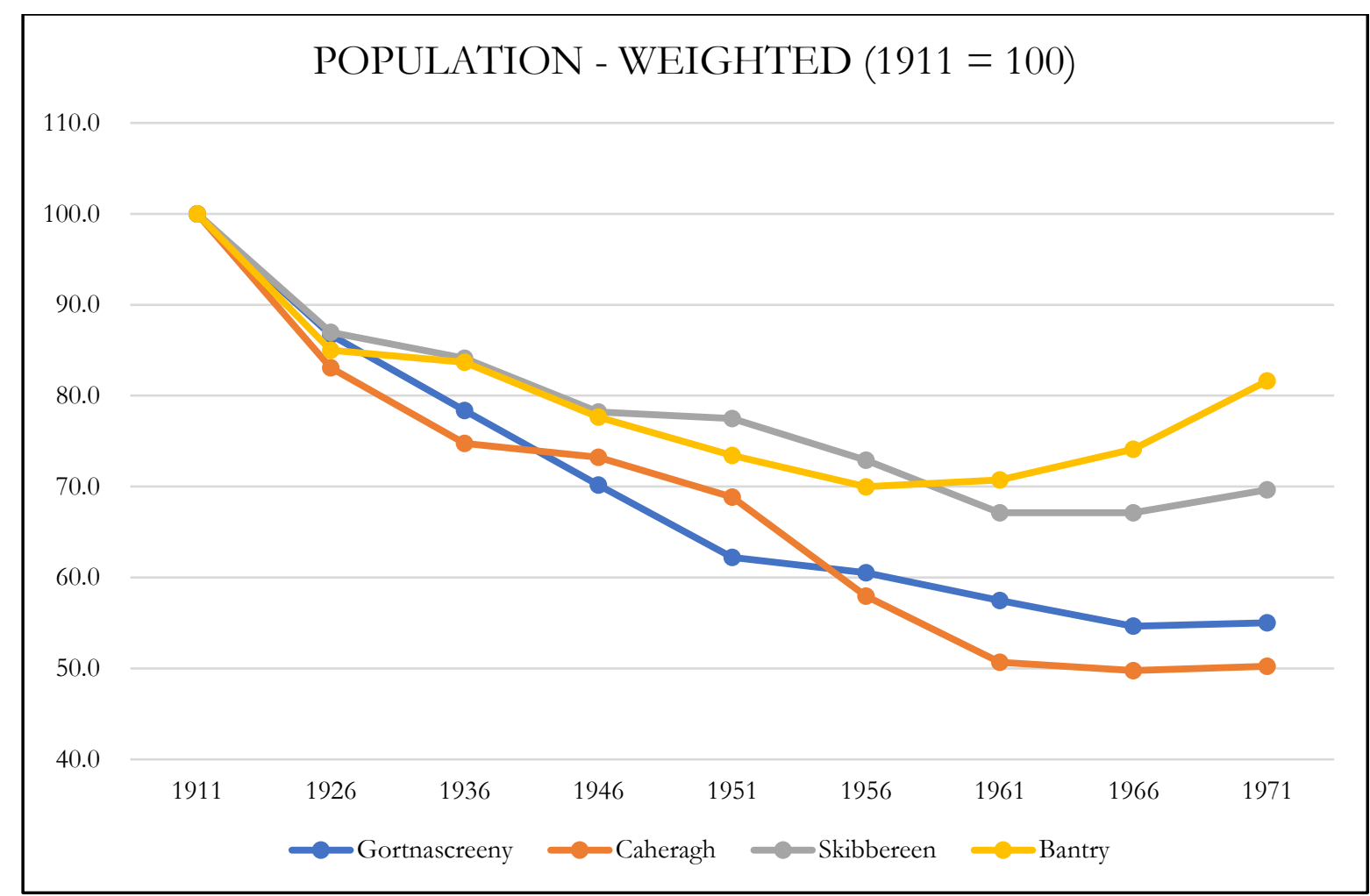

Fig. 5. Population figures for certain DEDs in west Cork, 1911-1971.

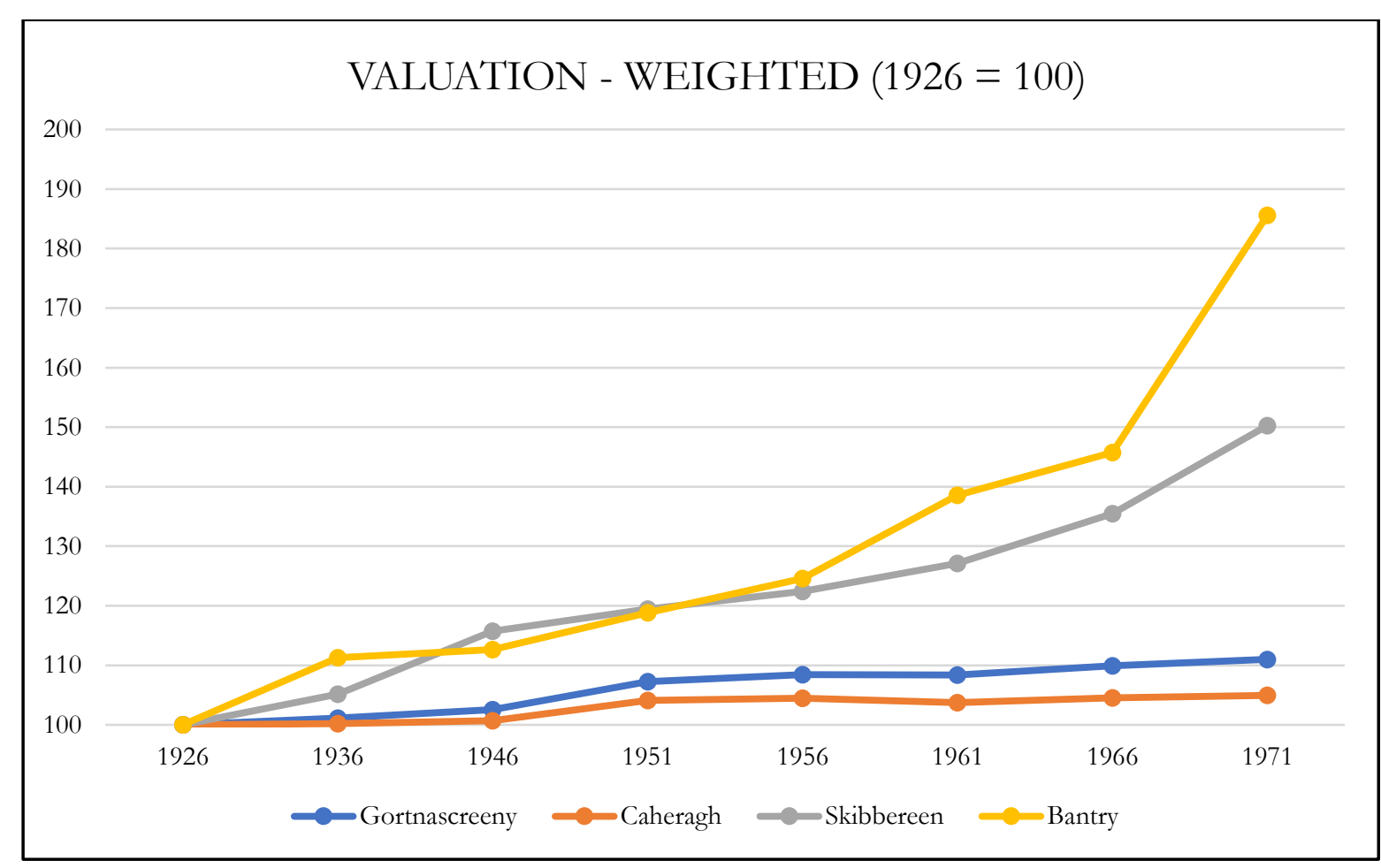

Fig. 6. Valuation figures for certain DEDs in west Cork, 1926-1971.

Henchy's strategy for building Dromore's new church was inspired by events he had experienced as a young cleric working in the diocese. Following his term as schools' inspector, he was appointed CC in Bandon, a large and mostly urban parish around $30 \mathrm{~km}$ south-west of Cork city, where he served between 1931 and 1935. Later, he reflected that his superior there, Canon 
Martin Murphy, as a 'great man for High Masses and processions' and as someone who took a special interest in building work. He was 'always doing things to the church and grave-yards'. ${ }^{56}$ Murphy's predecessor, Canon Jeremiah Cohalan (brother of the then-bishop of the diocese) had been a similarly enthusiastic church-builder in the parish; he oversaw the construction of a new chapel-of-ease in Gaggan in 1928-29. As CC, Henchy regularly said mass in this small church, designed by the Cork architect Bertie O'Flynn. ${ }^{57}$ In general size and architectural arrangement, it was very similar to what he later built in Dromore - and as a chapel-of-ease it would have been an obvious precedent to draw upon twenty years later. The church in Gaggan - and the process of building it - provided a blueprint that Henchy could later follow.

To raise the funds required to build Dromore, Henchy launched a sophisticated campaign of local charity events and took to writing in The Fold to win over the hearts and minds of his parishioners. In April 1954 he penned a short article 'Our new church at Dromore', which included a sketch drawing of the building (Fig. 7), closely matching what was later built. 'The old church' at Dromore, he argued,

'is beyond repair. From its sagging roof to its stone-flagged floor there comes a breath of decay. Its crumbling, blotched walls and stoke-hold-like sacristy are certainly not fit surroundings for the King of Kings. ... Just as its predecessor, the small thatched chapel -250 yards to the north - it has had its day.'

It had been built in the 1820s, at the same time as the energetic local PP, Fr. David Dore, rebuilt the main parish church in Caheragh. ${ }^{58}$ Yet Henchy saw practical benefit in speculating that it had been built somewhat earlier, at the time of the United Irishmen rebellion:

'It is said that the present church was begun in 1798. The people were so poor that they built the transept only. Then a Father Begley, about fifty years ago [sic later], completed the nave. The parish was in debt and a levy was put on the parishioners of one penny a month. It was a huge sum for the starving people of the time. History is repeating itself and I ... am proud to say that the present parishioners are worthy successors of the men and women who starved to build a house for God. ${ }^{59}$

\footnotetext{
${ }^{56}$ Henchy, 'Fifty Years a Priest', p. 17.

57 Southern Star, 15 th September 1928 and 21 st September 1929.

58 O'Sullivan and Harley, History of Caheragh Parish, pp. 83-93. David Dore served as PP of Caheragh between 1814 and his death in 1864 - see Cork and Ross Diocese biographical records, 'Very Rev. David Dore PP', (http:// corkandross.org/priests/very-rev-david-dore-pp-2) [access 13th January 2020]; and Pat Crowley, 'Old Caheragh church', West Cork History: History of Durrus/Muintervara blog, 31 st January 2016 (https://durrushistory.com/2016/01/31) [accessed 13th January 2020].

59 Patrick Henchy, 'Our New Church at Dromore', The Fold, April 1954, pp. 25-26. There are no records of a Fr. Begley serving in the parish c. 1900, but presumably Henchy is here referring to Michael Begley, CC of the parish between 1838 and 1847 - see Cork and Ross Diocese biographical records, 'Very Rev. Michael Begley PP', (http://corkandross.org/priests/very-rev-michael-begley-pp) [access 13 th January 2020]. The church is shown complete with nave and transepts in the 6" Ordnance Survey map for the area, surveyed in 1841 (sheet no. CK119).
} 


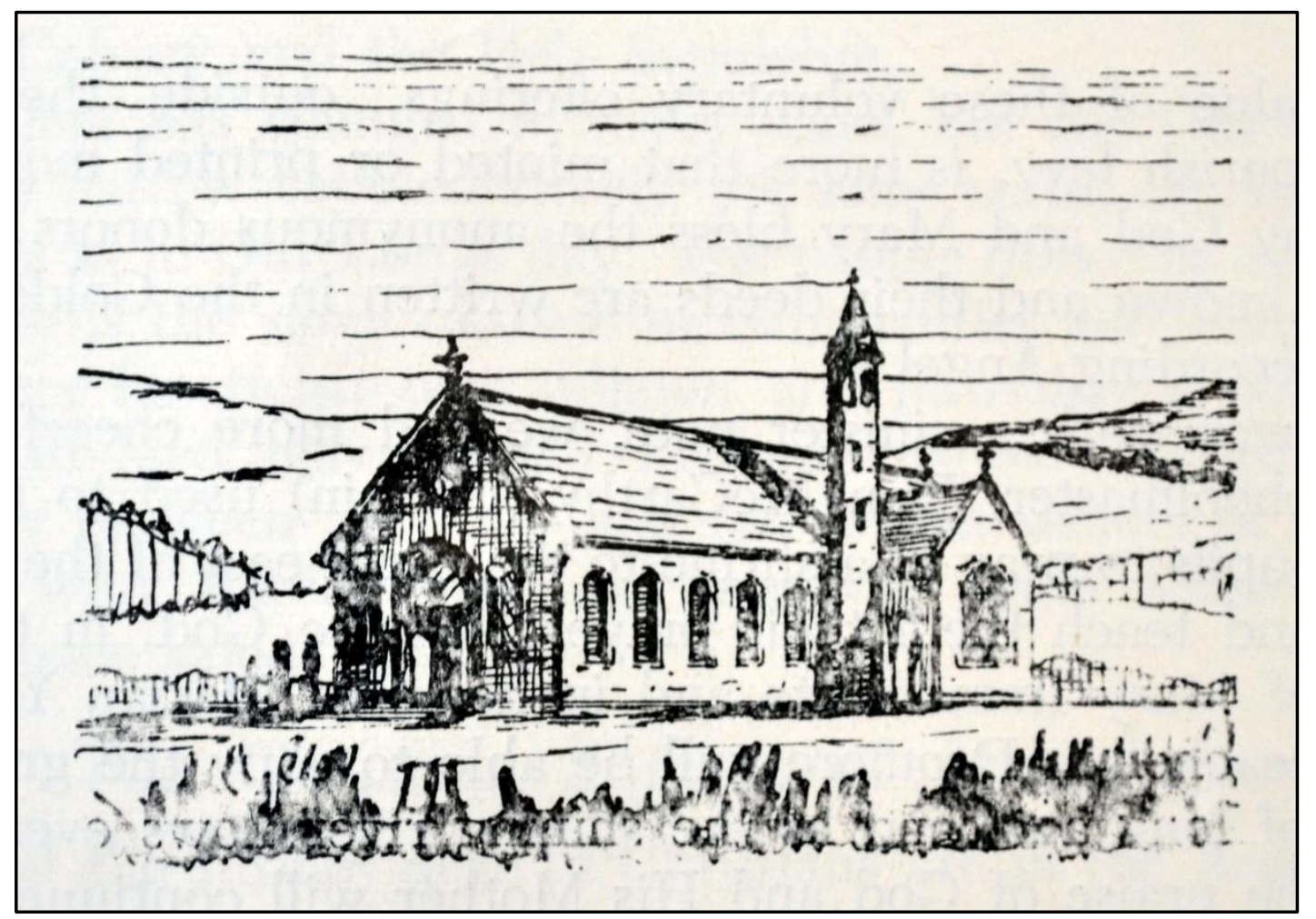

Fig. 7. Perspective sketch of Dromore church, from The Fold, April 1954, p. 25.

Henchy was probably not aware that according to local folklore, Dore had faced considerable resistance in his fundraising campaigns of the 1820s: 'the new walls' of his church in Caheragh 'were being pulled down at night by those who opposed its building', action that was only halted when Dore 'threatened to put a curse on those who were committing the damage'. ${ }^{60}$ A century and a quarter later, in such different political circumstances, Henchy faced no such opposition. As well as the offer of a site free-of-charge, he appointed collectors of funds for the various townlands in the parish, and the local Catholic Young Men's Society organised a raffle and performed a comedy to an 'almost full house' in Bantry to raise funds. ${ }^{61}$ The Men's Sacred Heart Confraternity in Henchy's former Cork city parish also made a significant donation. ${ }^{62}$ Henchy's success in raising money was all the more remarkable considering another new church was also being built at this time in the neighbouring parish of Drimoleague, and there the PP organised more than 25 separate fundraising events between 1952 and $1955 .{ }^{63}$ In such a sparsely populated rural area, weakened by decades of emigration, the building of two new churches at the same time undoubtedly placed a heavy burden on the local community.

The construction of Dromore church proceeded rapidly. Bishop Lucey visited twice in May 1954 to bless the site and, a fortnight later, to lay the foundation stone (Fig. 8) ${ }^{64}$ Regular updates on the project were published in the local newspaper. Initially, Henchy hoped to have the church opened during the Marian Year of 1954 but this proved a little too optimistic. ${ }^{65}$ By the summer of 1954 the floor had been laid, by September the walls were at roof height and it

${ }^{60}$ O'Sullivan and Harley, History of Caheragh Parish, p. 87. See also Delay, "'Language Which Will Move Their Hearts"', p. 426.

${ }^{61}$ Southern Star, 26 th December 1953 and 23 ${ }^{\text {td }}$ April 1955.

62 Southern Star, 26th December 1953.

${ }^{63}$ Butler, 'All Saints, Drimoleague, and Catholic Visual Culture under Bishop Cornelius Lucey', pp. 35-36.

${ }^{64}$ Southern Star, $1^{\text {st }}$ May 1954 and 29th May 1954.

${ }^{65}$ Southern Star, 17th July 1954 and 5th March 1955; Henchy, 'Fifty Years a Priest', p. 17. 
was noted the workers were receiving 'much encouragement and assistance' from their parish priest (Fig. 9) ${ }^{66}$ Volunteers from the parish helped with the building work, and posed for photographs with their bottles of beer on a warm summer's day (Fig. 10). By February 1955 the roof and much of the carpentry work were finished, with 'work on the belfry tower' ongoing, and by May the church was complete. ${ }^{67}$

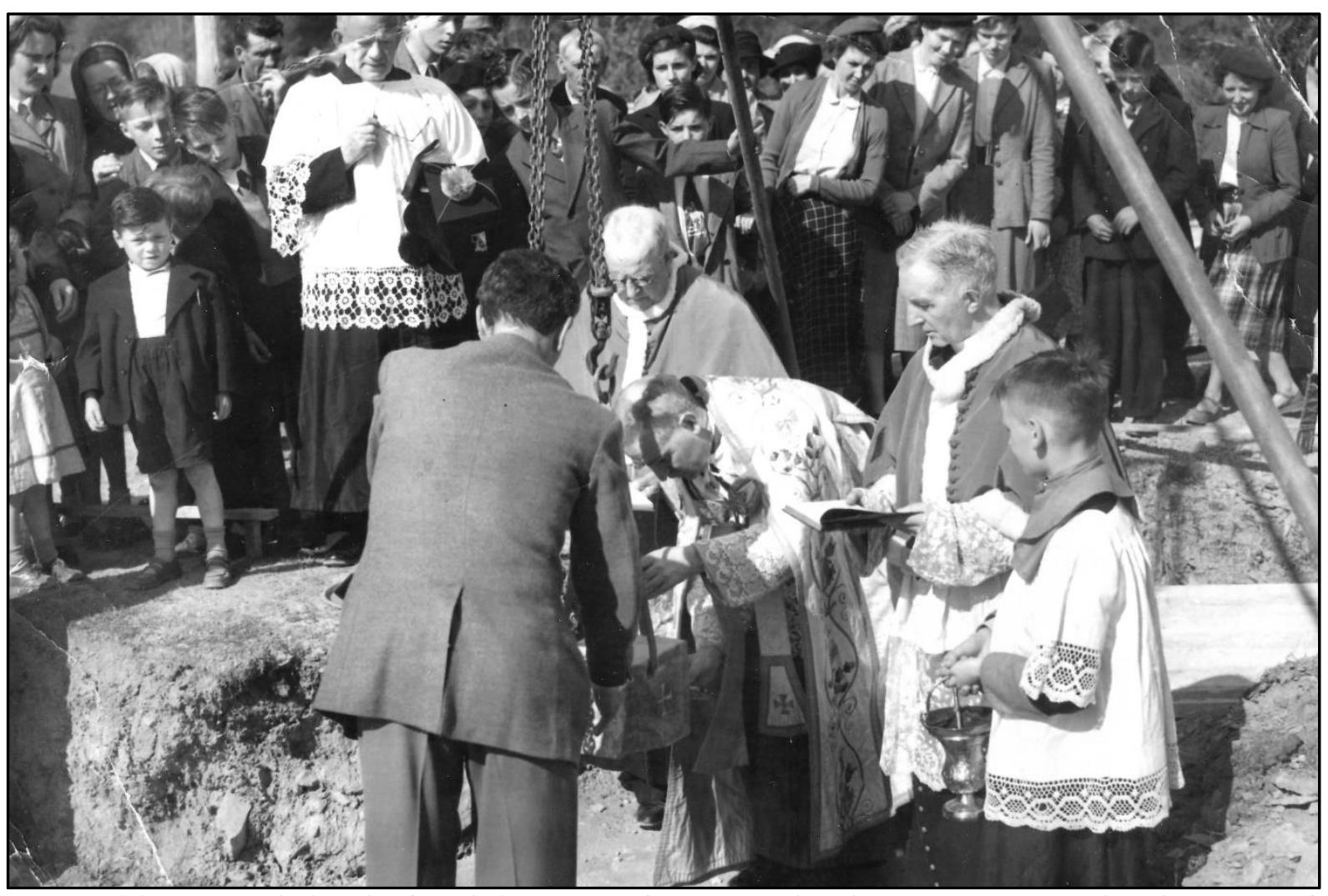

Fig. 8. Bishop Lucey laying the foundation stone of Dromore church, May 1954. Reproduced courtesy of Fr. Danny Pyburn, Dromore, and Mrs. Cecilia Wilcox, Dromore.

66 Southern Star, 17th July 1954 and 25th September 1954.

${ }^{67}$ Southern Star, 12 th February 1955, 19 th March 1955 and 30th April 1955. 


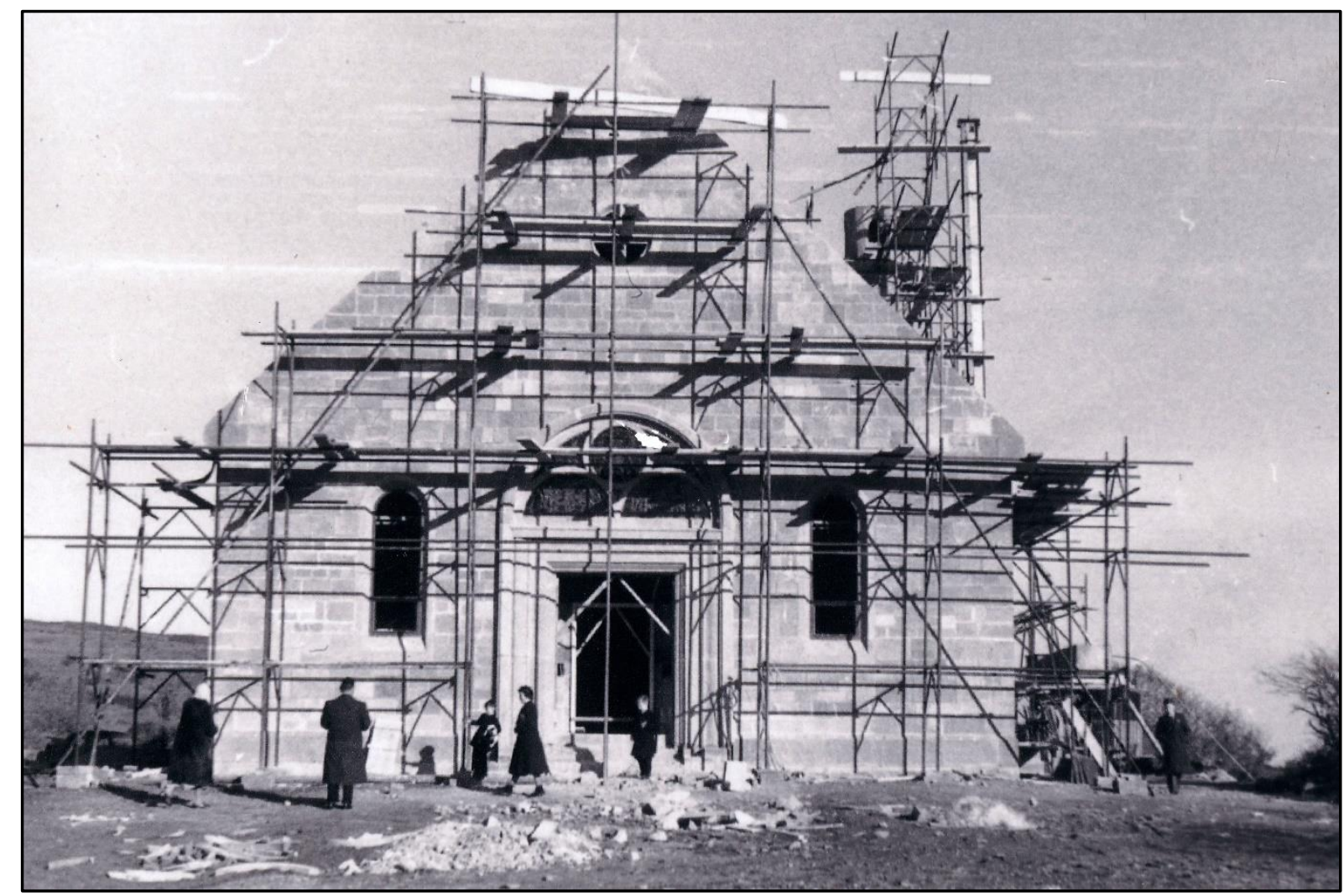

Fig. 9. Dromore church under construction. Photograph by Paddy O'Keeffe, 1954-55. Reproduced courtesy of Fr. Danny Pyburn, Dromore, and Mrs. Cecilia Wilcox, Dromore.

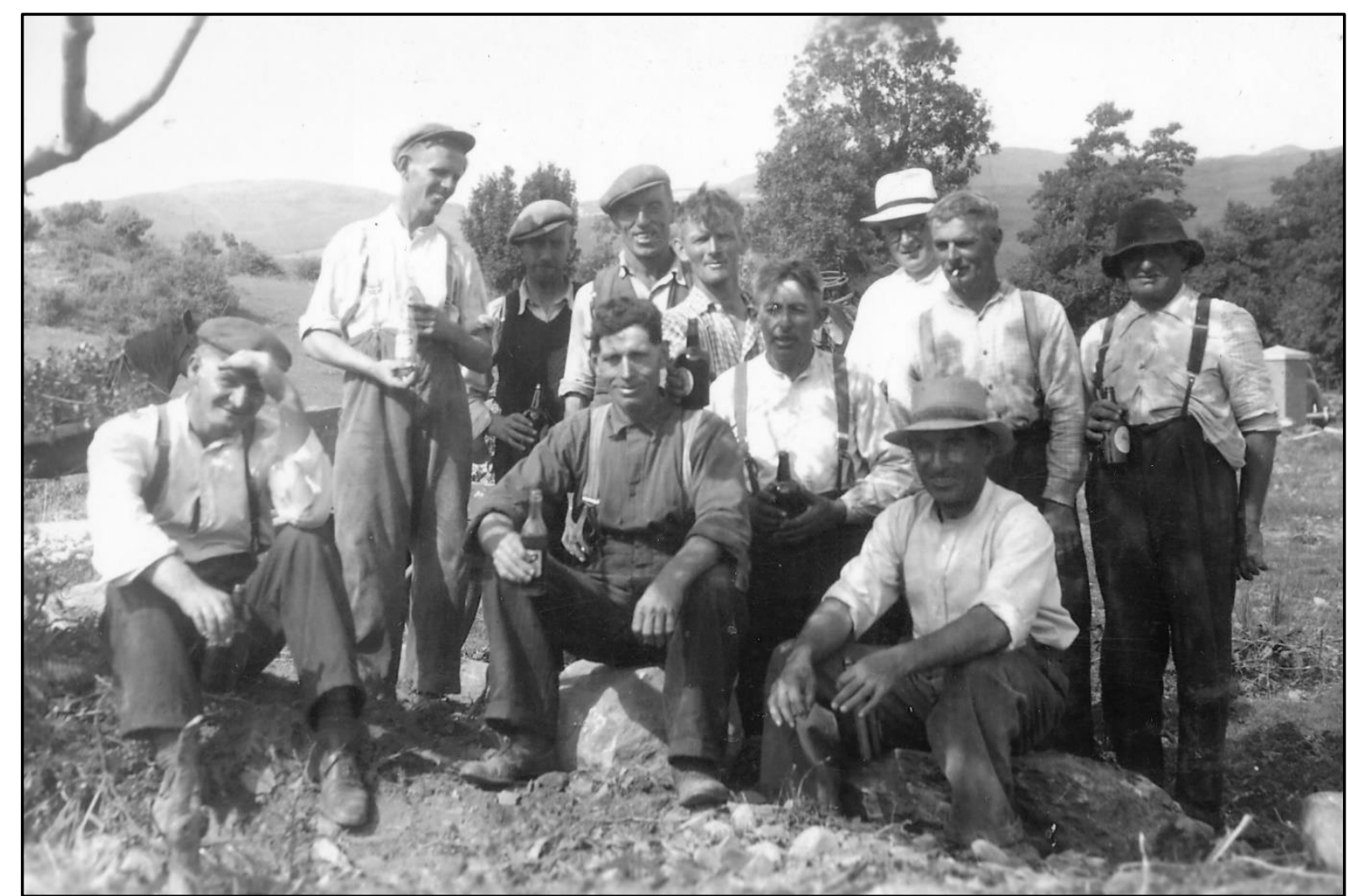

Fig. 10. Parishioners who volunteered to help build Dromore church. Photograph by Paddy O'Keeffe, 1954-55. Reproduced courtesy of Fr. Danny Pyburn, Dromore, and Mrs. Cecilia Wilcox, Dromore. 
Henchy was immensely proud of his new church, writing later that 'from the cutting of the first sod to the blessing and first Mass', the building work 'took only 356 days' ${ }^{68}$ Yet its consecration - a major public event to be considered shortly - was also a bitter-sweet moment for him, as within a week he received news from the bishop that he was to be transferred to another parish. 'It was lonesome leaving Caheragh', he wrote, adding that 'the happiest job I ever did was the building of the Church of Mary Immaculate in Dromore'. ${ }^{69}$ The swap was necessitated by Lucey's decision to split the Cork city parish of Blackrock into two separate entities and the subsequent need for an experienced, senior priest to take charge of a newly created parish (Ballinlough) in a rapidly growing suburb of the city. ${ }^{70}$ Cork's continued expansion came at Henchy's expense, and he was asked to back-fill the vacant PP post in nearby Dunmanway. Unlike Caheragh, his new parish 'had water and light,' but, he added, 'it took getting used to - the convent, the numerous schools, the big church and the two outside churches were all strange'. For church-building priests such as Henchy, being forced to move on from their adopted parishes must have been quite painful. Yet in Dunmanway he once again found solace in tidying the "paths and hedges in the [parish] cemetery'. ${ }^{71}$ Within a few years, in a different parish, he was once again engaged in building work. ${ }^{72}$

\section{Architecture, landscape and Marianism}

For Henchy, the architectural style of Dromore church, and especially its most prominent feature - an 18-metre-high concrete Round Tower emulating Irish Hiberno-Romanesque architecture (Fig. 11) - had clear political and cultural meanings. Challenging Fallon's accusation of philistinism, Henchy understood quite well the interplay between the design of the new church and its surrounding rural landscape. ${ }^{73}$ He sought to explain its iconography and symbolism to his parishioners in contributions to The Fold and the local newspaper. In choosing to adopt a distinctly 'Irish' style of architecture, Henchy followed, of course, in the wake of late nineteenth-century Irish cultural nationalism. There were, for example, perhaps a dozen other Catholic churches built between 1890 and 1955 that feature revivalist Hiberno-Romanesque motifs such as Round Towers. ${ }^{74}$ Furthermore, this stylistic decision was probably as much Henchy's as it was Dromore's architect, Henry (Harry) Fitzgerald-Smith, as Henchy wrote so extensively about the design, and Fitzgerald-Smith generally followed more contemporary trends in his other known works. Dromore's traditionalism was thus an outlier within this architect's oeuvre. $^{75}$

\footnotetext{
${ }^{68}$ Henchy, 'Fifty Years a Priest', p. 17.

${ }^{69}$ Henchy, 'Fifty Years a Priest', p. 17.

70 Southern Star, 14th May 1955; Cork and Ross Diocese biographical records, 'Very Rev. Canon Edward J. Fitzgerald PP', (http:// corkandross.org/priests/very-rev-canon-edward-j-fitzgerald-pp-2) [access 14th January 2020].

${ }^{71}$ Henchy, 'Fifty Years a Priest', pp. 17-18.

${ }^{72}$ Henchy, 'Crosshaven by the Sea', pp. 32-34.

${ }^{73}$ Martin Maguire, 'Churches and Symbolic Power in the Irish Landscape', Landscapes, 5:2 (2004), pp. 91113, at pp. 100-107.

${ }^{74}$ Alistair Rowan, 'The Irishness of Irish Architecture', Architectural History, 40 (1997), pp. 1-23, at pp. 3-5 and 21-22; Sean O'Reilly, 'Birth of a Nation's Symbol: The Revival of Ireland's Round Towers', Irish Arts Review Yearbook, 15 (1999), pp. 27-33; John Turpin, 'Visual Culture and Catholicism in the Irish Free State, 1922-1949', Journal of Ecclesiastical History, 57:1 (January 2006), pp. 55-77, at pp. 65-69.

${ }^{75}$ Irish Builder and Engineer, 96:8 (10 ${ }^{\text {th }}$ April 1954), p. 364. See for example his church at Farranree in Cork city (one of Lucey's 'Rosary' churches), built in 1957-59, or his Faber-Castell factory in Fermoy, Co. Cork, opened in 1966; Patrick M. Delany (ed.), Architectural Survey, 1959 (Dublin, 1959), p. 8; Irish Independent, 6th September 1966.
} 
Architecturally, Dromore church was quite straightforward: a single large hall arranged on a traditional east-west axis, around 30 metres by 12, with a small chancel to the east and a sacristy in a south wing. ${ }^{76}$ Round-headed windows, in a pared-down Romanesque style, are used throughout (decorated with stained glass to be discussed shortly). In featuring an asymmetrically placed Round Tower and Celtic crosses on its gables, the design follows closely the Honan Chapel (Fig. 12), a Celtic Revival church of international renown at University College Cork, designed by James McMullen and built in 1915-16 (during which time Henchy was working in the city). ${ }^{77}$ McMullen in turn borrowed from a wealth of medieval architecture in the south of Ireland, not least St. Crónán's in Roscrea, Co. Tipperary, and nineteenth-century imitations such as Daniel O'Connell's round tower mausoleum at Glasnevin, Dublin, completed in $1869 .{ }^{78}$ In designing Dromore church, Henchy and Fitzgerald-Smith may also have been aware of the Round Tower, dated 1843, adjacent to a church at Waterloo, north of Cork city, or, closer to Henchy's former Bandon parish, the church at Timoleague, built in 1907-11, which also featured a prominent Round Tower. ${ }^{79}$ Other new churches with Round Towers included St. Patrick's in Donegal town (consecrated in 1935) and a church on Merrion Road in south Dublin (Fig. 13), designed by Simon Aloysius Leonard and built in the early 1950s. ${ }^{80}$ By the mid-1950s, such traditionalism was hotly contested within Irish architectural circles. This was evident, for example, in the clash between modernists and more conservative voices at the 'Church Architecture Today' symposium held in Dublin in June 1955. For the writer Stephen Rynne, many church architects were 'yes men' to their clerical patrons: there were, he felt, 'a lot of yes buildings around the country'. He criticised what he termed 'flag-waving' and 'nailing ourselves to the Cross of Cong to prove our nationality'. In a similar vein, architects such as Liam McCormick and Michael Scott, firmly rooted in the modernist school, advocated for international influence and an escape from historicism. By contrast, John J. Robinson, who went on to build Galway Cathedral, saw reasons to celebrate reviving traditional styles in contemporary building. ${ }^{81}$ The architecture of Dromore church left little doubt about the aesthetic preferences of its parish priest, whatever of his architect.

\footnotetext{
${ }^{76}$ Some alterations to the structure and layout of the church were made in 1966 by J. R. Boyd Barrett see elevation, plan, and section drawings dated December 1964 (Cork \& Ross Diocesan Archives, Cork); correspondence with Mrs. Cecilia Wilcox and Fr. Danny Pyburn, Dromore, Co. Cork, 25th September 2016.

${ }^{77}$ M. J. O'Kelly, 'The Honan Chapel', The Furrow, 1:6 (July 1950), pp. 290-96; Michael Morris [Lord Killanin] and Michael Duignan, The Shell Guide to Ireland (London, 1967), p. 188. Paul Larmour, 'The Honan Chapel, Cork: A Shrine to the Irish Arts and Crafts Movement', Irish Architectural and Decorative Studies, 5 (2002), pp. 22-47; Fergus Ryan, 'Iconography of the Honan Chapel: Symphony of a Single Idea?', Proceedings of the Royal Irish Academy, 119C (2019), pp. 283-305.

${ }^{78}$ Killanin and Duignan, Shell Guide, pp. 415-16; Jeanne Sheehy, The Rediscovery of Ireland's Past: The Celtic Revival, 1830-1930 (London, 1980), pp. 58-60.

79 The date 1843 is inscribed on the tower at Waterloo; Sheehy, Rediscovery of Ireland's Past, pp. 62-63;

Dictionary of Irish Architects (www.dia.ie) [accessed 27th January 2020].

80 Irish Press, $8^{\text {th }}$ March 1935; Irish Builder and Engineer, 94:11 (24 $4^{\text {th }}$ May 1952), p. 544.

${ }^{81}$ Irish Builder and Engineer, 97:10 (7th May 1955), pp. 461-62. For a full account, see The Furrow, 6:6 (June 1955), pp. 338-80 and many other articles in the same journal from the early 1950s.
} 


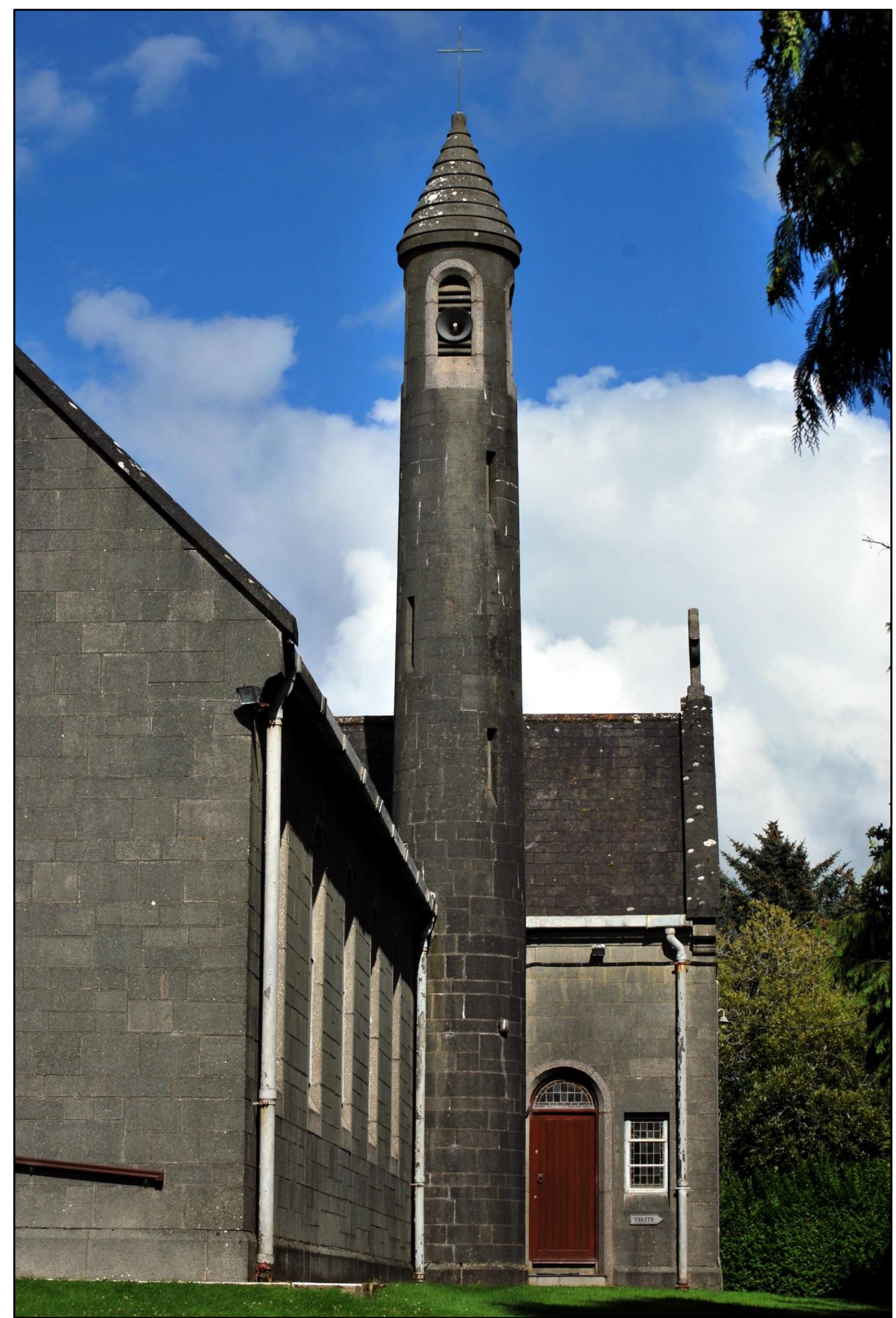

Fig. 11. Dromore church. Photograph by author, 2012. 


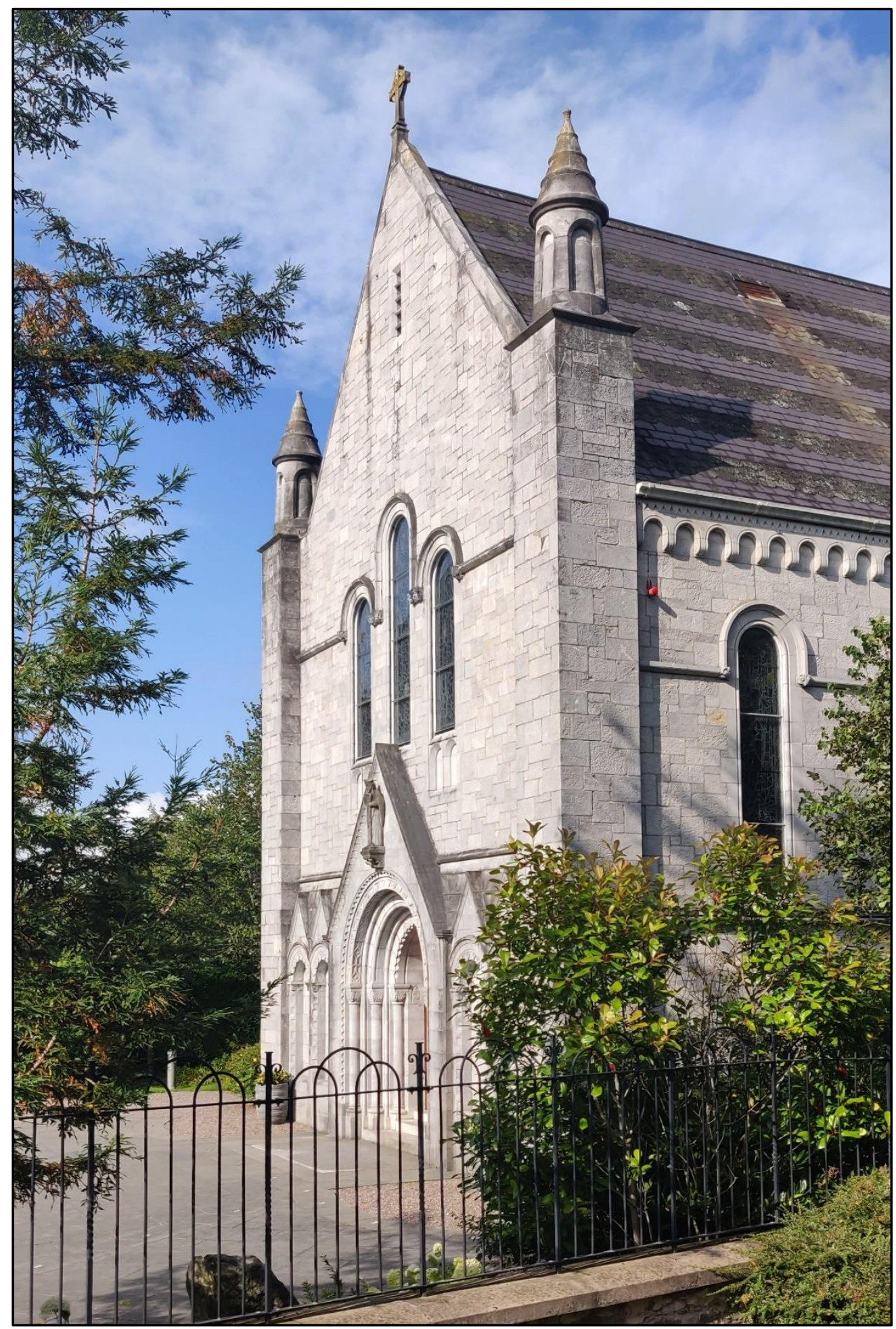

Fig. 12. The Honan Chapel, University College Cork. Photograph by author, 2019. 


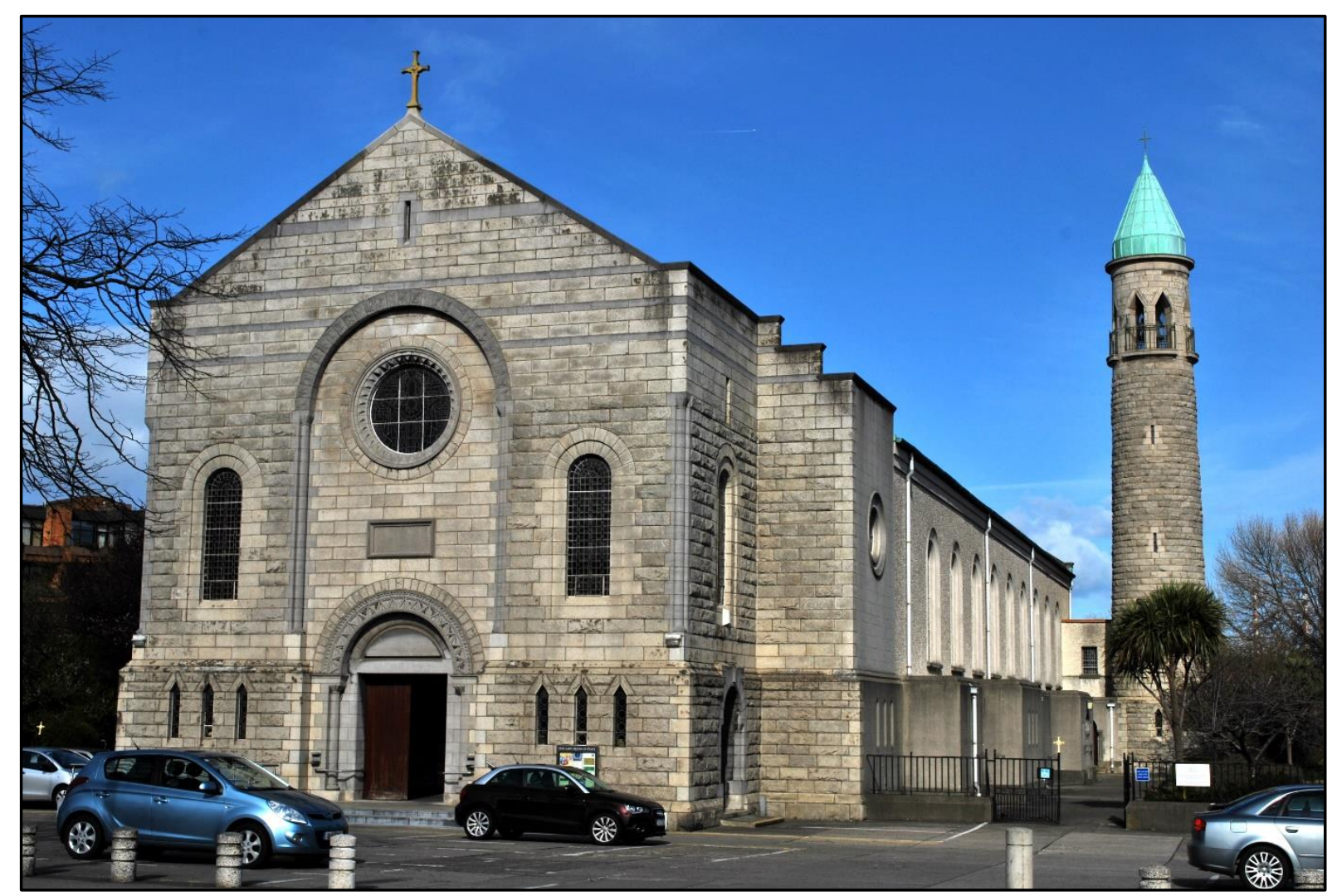

Fig. 13. Church of Our Lady Queen of Peace, Merrion Road, south Dublin. Photograph by author, 2012.

Henchy imbued his new church with a rich array of political symbolism and meaning. ${ }^{82}$ Its design was sufficiently advanced by April 1954 for him to promote the project in The Fold. Alongside the perspective sketch mentioned earlier, he introduced the folklore of the surrounding valley and, in particular, a pass through the hills shown on Ordnance Survey maps as the 'Murdering Glen' (visible to the right of Fig. 1 above). This road, formerly an important thoroughfare, was remembered in folklore as a site of theft and murder of passing travellers in centuries past, and its lawlessness was described by John Windele in 1839 as: 'a wild and lonely pass, ... the retreat of daring outlaws, whose deeds acquired for it its sanguinary title'. ${ }^{83}$ Jagged protruding rocks and boulders gave it a foreboding appearance, which Henchy had learned of soon after his move to the parish. He commented that:

'Here a murderess and her son lived. Her reddened knife and blunderbuss were the terror of the travellers. Her son was caught and taken to Cork. He was sentenced to be hanged. On the scaffold he told of treasures he had buried in Dromore hill. These were never found. All that remains now is the cave and the overhanging jutting rock .... The hill of Dromore still hides the fabled pot of gold. ${ }^{84}$

\footnotetext{
82 Delay, “Language Which Will Move Their Hearts”, p. 452.

${ }^{83}$ John Windele, Historical and Descriptive Notices of the City of Cork and its Vicinity; Gougaun-Barra, Glengariff, and Killarney (Cork, 1839), p. 271. The folklore of the 'Murdering Glen' is also richly documented in the 1930s Schools' Collection project: see Michael Keohane, Dromore, Co. Cork, National Folklore Collection, UCD, Schools' Collection, pp. 15-17 (https://www.duchas.ie/en/cbes/4921613/4885103) [accessed 27th January 2020].

${ }^{84}$ Henchy, 'Our New Church at Dromore', p. 25.
} 
Into this landscape of violence and the exercise of (British colonial) judicial authority stepped Henchy's new church. 'Another mother's dwelling place', he wrote, 'will soon rise near this ill-omened spot. Her Son, too, was put to death as a criminal, but not before He gave to us His treasure. ${ }^{85}$ Seeking to link architecture, landscape and history, he interpreted the church's traditional 'Irish' motifs of Round Tower and Celtic crosses using militaristic language that echoed his earlier writings on the 'victorious' Holy Year cross nearby:

'Coming southwards over the hills towards Dromore you see a splendid tower. It rises in tapering roundness to a cross-topped point. It is like the lifted lance of a warrior guarding the pass of the murdering glen. The steel blue slated roof might be the armour of the sentinel but all thoughts of strife disappear when you notice the Celtic crosses on the gables. Their quiet serenity is emphasised by the stone circles linking the outstretched arms of the torture tree of Christ. He died for all and His reign is for eternity, a circle is all embracing and has no beginning or end.'

He believed that his new church, despite its embrace of concrete blocks and other modern building materials, fitted with organic neatness into the surrounding rural landscape, writing that 'the colour of the walls fits in with the rocks around so well that the church seems to have grown out of the ground' and that 'the rounded arches of the windows and door correspond with the curves of the hills. ${ }^{86}$

This marriage of architecture and landscape also had a distinct - if rather surprising political meaning for Henchy: he used it to champion conservative social values and to demonise of any kind of socialist politics. In a rambling contribution to The Fold on the eve of the church's consecration, ostensibly on the subject of 'mass rocks', he attempted to bring together the legacy of Cromwell in Ireland, his new church, the rural landscape, and the contemporary politics of post-war Europe. ${ }^{87}$ Mass rocks, scattered in significant numbers in the vicinity of Dromore, served as altars for the saying of mass in the Irish countryside during the time of the Penal Laws from the mid-seventeenth century to the early nineteenth century. ${ }^{88}$ The 'message from the mass rocks', as Henchy termed it, was one of perseverance in the face of adversity from the 'Cromwellian generals': these secret sites of worship had been 'planted on the mountain side by the hunted priest' like 'the tiny seed of the gospel'. Now, in an independent Irish republic, the Catholic Church had reversed its fortunes: the seed was now 'a mighty tree', he wrote, that showed 'its power and grandeur over all the land'. He saw in the rural landscape proof of the cultural revival and Catholic triumphalism of his youth, into which, he penned with poetic energy, would now sit his new Hiberno-Romanesque church:

'It is evening, the golden red rays of the setting sun transform the rugged ranges of the hills into shining towers and gleaming battlements. To the north-west the Kerry mountains are blue-black shadows on the horizon. Standing on a summit, I think of the great priests and people who lived in this land; of their great faith which, when driven underground, gained strength .... I thank God that the new Church of 'Mary

\footnotetext{
85 Henchy, 'Our New Church at Dromore', p. 25.

86 Southern Star, 30th April 1955. See also Patrick Henchy, 'The New Church of Mary Immaculate at Dromore', The Fold, May 1955, p. 34.

${ }^{87}$ Patrick Henchy, 'Mass Rocks', The Fold, April 1955, pp. 30-33. For a broader overview here, see Sarah Covington, "'The Odious Demon from Across the Sea": Oliver Cromwell, Memory and the Dislocations of Ireland', in Erika Kuijpers et al. (eds), Memory Before Modernity: Practices of Memory in Early Modern Europe (Leiden, 2013), pp. 149-64, at pp. 152-53.

88 See for example Southern Star, 9th April 1955 and anon. [very likely Patrick Henchy], 'Mass Rocks at Caheragh', The Fold, June 1963, pp. 33-37; O'Sullivan and Harley, History of Caheragh Parish, pp. 81-82.
} 
Immaculate' dominating the valley of Dromore mirrors again the living strength and power of the same Faith which gathered our forefathers round the Mass rocks of the high hills long ago.'

However, rather than ending his essay here, he appended a final paragraph that warned of the threats posed to Ireland by Communism, presenting it as a post-war menace comparable to Cromwell's actions three hundred years before. He issued a rallying call to the Catholic faithful, warning of the coming 'battles' and of a need to defeat the 'twisted creed symbolised by the crooked cross of the hammer and the sickle and the clenched fist so like the paw of a beast'. 'We will never retreat or panic', he claimed, 'before the blood-stained hordes of Communism'. ${ }^{89}$ Such 'red scare' language was a dramatic shift from his typical rural antiquarianism, but it must be seen in the context of the Irish Catholic Church's vocal condemnation of left politics at home, and across European from Irish Catholic involvement in the Spanish Civil War to the Soviet persecution of Catholics in Hungary, Yugoslavia and elsewhere after $1945 .{ }^{90}$ In laying down a challenge to the (essentially non-existent) left politics of 1950s rural west Cork, Henchy followed the lead of Lucey, who regularly extolled the dangers of any kind of socialism in sermons while on the annual 'Confirmation' rounds. ${ }^{91}$ Other bishops - most notably Michael Browne in Galway - took their anti-Communism almost to the point of obsession in these years. ${ }^{92}$ Henchy's comments show how a hostility to left politics could be rooted in a particular reading of the rural landscape - and in the loudly proclaimed 'Irishness' of the architecture of a new church.

At the heart of the building of Dromore church was Henchy's - and his parishioners profound devotion to Mary. Every aspect of the church's planning, fundraising, building, and ornamentation was deeply intertwined with the Catholic Marian Year celebrations from December 1953 to December 1954 - one of the most important religious and cultural events of post-war Ireland. ${ }^{93}$ As Delay and Liger have recently commented, 'Mary presented a model of Irish womanhood markedly different from the modern, independent English woman.' 'She symbolized', they suggest, 'sacrificial, selfless motherhood, which the emerging Irish nation promoted as women's singularly valuable role. ${ }^{94}$ Marianism in Ireland intensified during - and as a response to - the 'devotional revolution' of the nineteenth century. ${ }^{95}$ During 1954 , countless new Marian shrines and grottos were (re)built throughout Ireland as acts of both official and popular devotion - a cultural legacy that is only now beginning to be chronicled. ${ }^{96}$ Even the state, for example, issued a special commemorative stamp (Fig. 14) to mark the year. ${ }^{97}$ In

${ }^{89}$ Henchy, 'Mass Rocks', pp. 30-33.

${ }^{90}$ Enda Delaney, 'Anti-Communism in the Mid-Twentieth-Century Ireland', The English Historical Review, 126:521 (August 2011), pp. 878-903.

${ }_{11}$ Southern Star, $10^{\text {th }}$ May 1952. See also anon., 'Catholics under Communist Rule', The Fold, 2:3

(September 1954), p. 39; Cornelius Lucey, 'Socialism Condemned', The Fold, 2:11 (May 1955), p. 30;

Blanshard, The Irish and Catholic Power, pp. 55-61; and Sheehy, Is Ireland Dying?, pp. 184-98.

${ }^{2}$ Connacht Sentinel, 4th January 1949; Gerard Madden, 'Bishop Michael Browne of Galway and Anti-

Communism', Saothar 39 (2014), pp. 21-31.

93 Southern Star, 17th July 1954.

${ }^{94}$ Delay and Liger, 'Bad Mothers and Dirty Lousers', p. 8.

${ }^{95}$ Donnelly, 'The Peak of Marianism in Ireland', pp. 252-83; Donnelly, 'Opposing the "modern world"', pp. 183-245; Eugene Hynes, The Virgin's Apparition in Nineteenth-Century Ireland (Cork, 2009), pp. 91-128 and 253-66.

${ }^{96}$ See for example Southern Star, 13 $3^{\text {th }}$ March 1954, 18 th September 1954 and 20th November 1954. See also de Cléir, Popular Catholicism in 20th-Century Ireland, pp. 90-92; Finola Finlay and Robert Harris, 'Wayside Miracles', Roaringwater Journal, 26 ${ }^{\text {th }}$ July 2015 (https://roaringwaterjournal.com/tag/wayside-shrinesireland) [accessed $28^{\text {th }}$ January 2020].

97 Southern Star, 29 th May 1954. 
Dromore, Henchy's Marian devotion extended beyond the name of the church to include its programme of stained glass and statuary. In the same way as he sought to explain its architectural style to parishioners through the newspapers and The Fold, he also wrote about its ornamentation. 'A stained-glass window', he thought, 'can tell a story with deep spiritual significance'. Above the main door of the church, a semi-circular window by the Dublin firm of Earley \& Co (Fig. 15) shows three scenes: Mary crowned queen of heaven in the centre, flanked by depictions of the Visitation and the Holy Family. ${ }^{98} \mathrm{~A}$ rich blue is used throughout to emphasise the Marian dedication. The 13 side windows are decorated with small medallions including St. Joseph's lily ('he must be remembered in the house of Mary', Henchy thought), 'M.R.' (for Maria Regina), 'B.V.M.' (Blessed Virgin Mary), a star (symbolising 'Mary the Star of the Sea'), and a red rose (symbolising Mary's love). Henchy gave a brief theological explanation for each of these in his writings, but felt little need to go into any depth as, he thought, 'any Catholic understands [them]. ${ }^{99}$ On either side of the altar, small niches contain statues taken from the old church, of Mary and Joseph, and outside, to complete the ensemble, parishioners built a Marian grotto. ${ }^{100}$

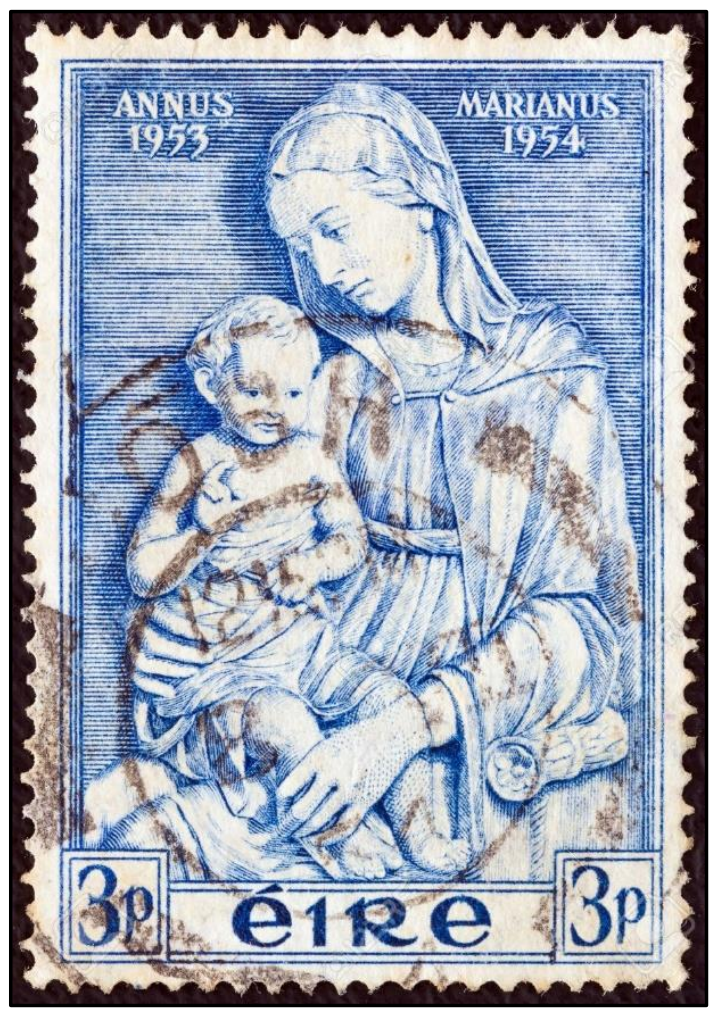

Fig. 14. A 'Marian Year' stamp. Photograph by author.

\footnotetext{
98 Southern Star, $7^{\text {th }}$ May 1955. I am grateful to Finola Finlay, George Walsh and David Caron for assistance identifying the designer of this window.

99 Southern Star, 5th March 1955 and 30th April 1955; Holland, History of Caberagh Parish, pp. 7-8.

100 Southern Star, 30th April 1955.
} 


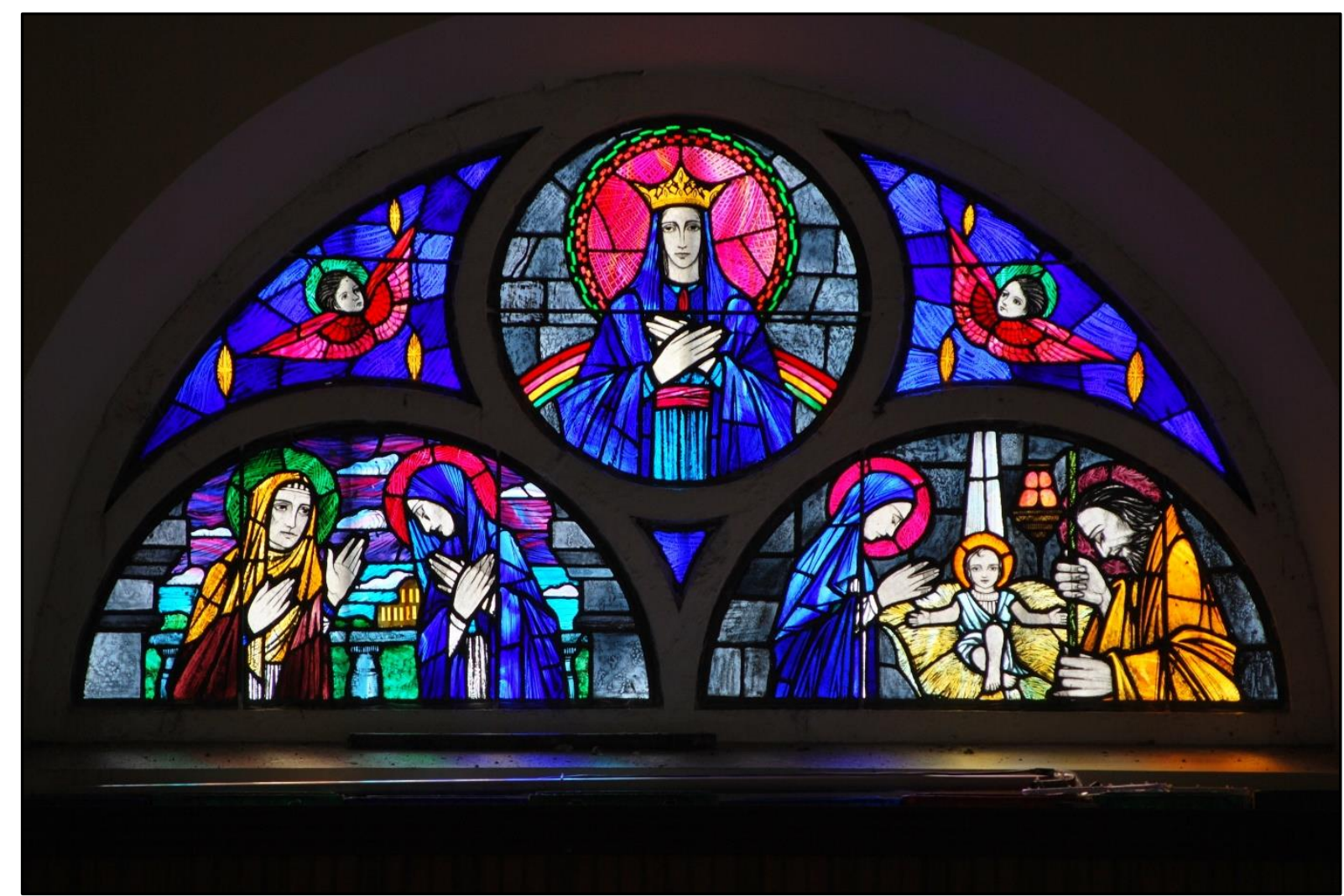

Fig. 15. Dromore church, stained glass window by Earley \& Co, 1955. Photograph by author, 2016.

\section{Performance and piety}

The consecration of a new church offered many opportunities for celebration, triumphalist rhetoric, as well as displays of public devotion. As Niamh NicGhabhann has recently commented relating to an earlier period in Irish Catholic church building, these events were 'significant public and visible expressions of the Roman Catholic community', which, she argues, 'were explicitly used as opportunities to define and display an increasingly confident and powerful Roman Catholic identity'. ${ }^{101}$ The building of Dromore's new church was the outcome of many different agendas, and these were all represented at its consecration in May 1955: it was, of course, a huge personal achievement for Henchy and his campaign, against all odds, to raise the funding necessary to build the church. It marked the first new church to be consecrated in rural west Cork since 1932 - the longest gap since the 1790 s. ${ }^{102}$ Furthermore, it was the first new church to be built during Lucey's time as bishop - and served as the prelude to his five new city churches that were all then under construction or being planned. Finally, it marked the achievement (and Marian devotion) of a rural community that had seen their numbers fall relentlessly for over a century. 'The road leading to the church', the Southern Star commented, 'was spanned by buntings, while the precincts of the church were also decorated.' Overall 1,000 people crammed into and around the new church (with a seating capacity for just 400): the newspaper noted that 'several hundred people ... knelt in the precincts.' In what was probably

${ }^{101}$ Delay, “'Language Which Will Move Their Hearts”; Niamh NicGhabhann, “'A Development of Practical Catholic Emancipation": Laying the Foundations for the Roman Catholic Urban Landscape, 1850-1900', Urban History, 46:1 (February 2019), pp. 44-61, at pp. 49-50. See also Richard J. Butler, 'The Afterlives of Galway Jail, "Difficult" Heritage, and the Maamtrasna Murders: Representations of an Irish Urban Space, 1882-2018', Irish Historical Studies (forthcoming November 2020).

102 Southern Star, $9^{\text {th }}$ April 1932; Tom Hayes (ed.), Cork and Ross Church Directory 2008 (Cork, 2008). 
the largest gathering in the parish for many years, photographs by a prominent local historian, who evidently realised the significance of the day, show that megaphones were required (Fig. 16) to relay the ceremony to those unable to squeeze into the church. ${ }^{103}$ Around 70 clergy attended, some forming a choir for the ceremony, while a special guest of honour was the Rev. Donal Keohane, home from Durant, Oklahoma, whose brother had donated the site. ${ }^{104}$

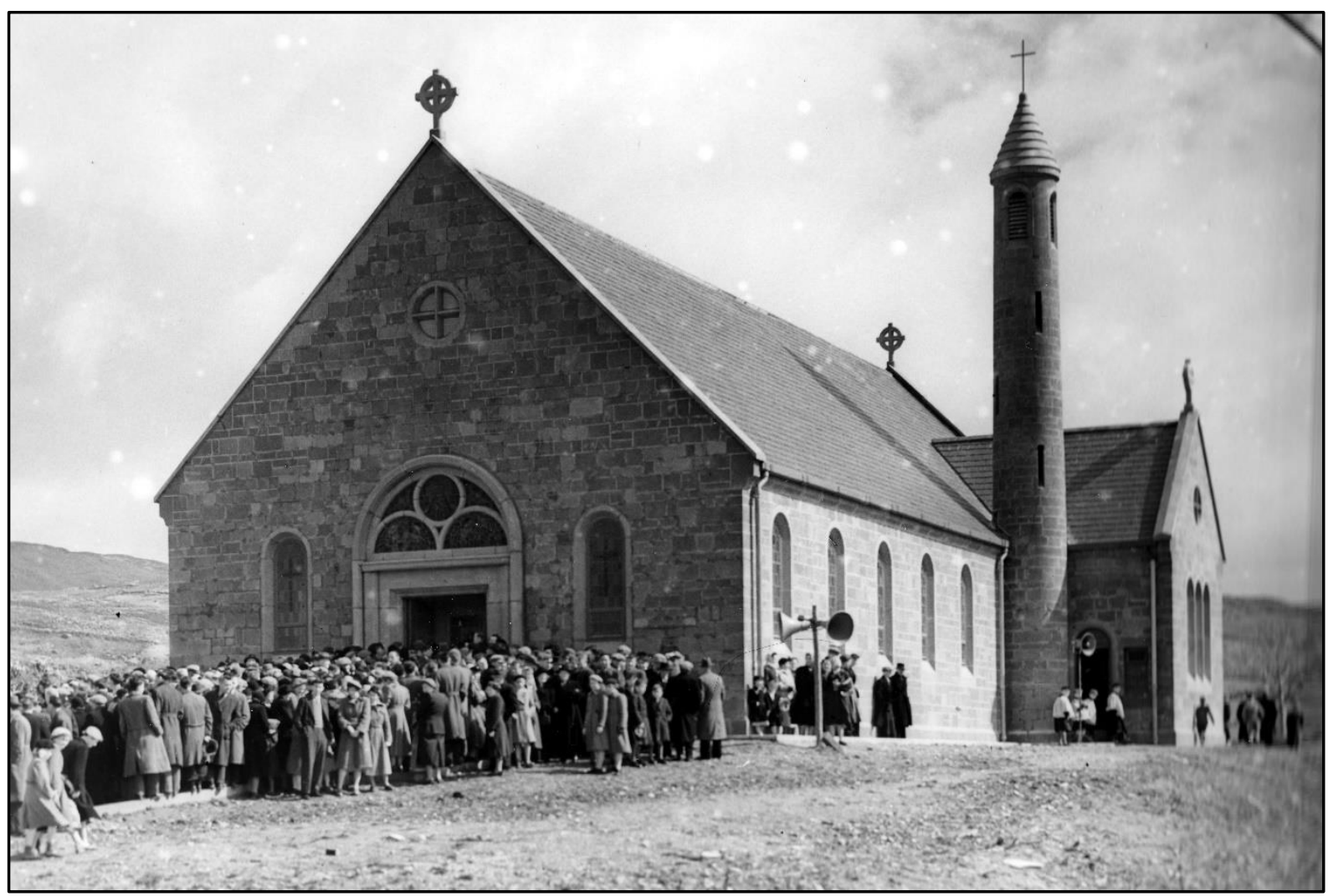

Fig. 16. The consecration of Dromore church. Photograph by Paddy O'Keeffe, May 1955. Reproduced courtesy of Fr. Danny Pyburn, Dromore, and Mrs. Cecilia Wilcox, Dromore.

In choosing who should give the sermon at the consecration, Henchy made clear his preference for the general tone of the event. Considering the colour of his antiquarian, religious, and political writings, it is not surprising that he chose Monsignor Joseph Scannell (ca. 18791961), the dean of the diocese. Scannell had an illustrious career that matched Henchy's militaristic writings: both men had briefly overlapped in the diocesan seminary before Scannell went abroad as chaplain to the Irish Guards during the First World War (for which he was awarded the Military Ross and the Croix de Guerre). Under the new regime, he served as the first chaplain to the Irish Free State forces in Collins Barracks in Cork during the Civil War, during which time he oversaw the dedication of the Garrison Chapel there as a place of Catholic worship. In 1927, he was invited to unveil the First World War Memorial in Cork city, and later he served as president of the diocesan seminary for almost twenty years. ${ }^{105}$ When Scannell was invited to give the sermon at the consecration of a new church at Drinagh in 1932 - the last to

103 Photographs of the consecration of Dromore church by Paddy O'Keeffe, Bantry, 4th May 1955 (copies displayed in Dromore church, Co. Cork).

104 Southern Star, 30th April 1955 and $7^{\text {th }}$ May 1955; Irish Independent, 5 th May 1955.

${ }^{105}$ Cork and Ross Diocese biographical records, 'Mgr. Joseph Augustine Scannell PP VG', (http://corkandross.org/priests/mgr-joseph-augustine-scannell-pp-vg) [access 29th January 2020]. 
be built in west Cork before Dromore - a young Henchy was in the audience to hear his remarks. ${ }^{106}$ Anticipating the beginning of the International Eucharistic Congress in Dublin, Scannell then played to Catholic nationalist sensibilities by recalling, as Henchy would later emulate, the 'ruined shrines' and the 'poor, gaping, voiceless mouths' of Catholic persecution during the Penal Laws. The building of a new church was, Scannell suggested, in the 'best traditions of Irish nationality', and he proudly referred to the church as 'our public cult'. ${ }^{107}$ Twenty-three years later in Dromore, following some brief remarks from Lucey, Scannell adopted a similar tone, referencing Henchy's writings about mass rocks and the parish's ongoing struggles with poverty and emigration in a remarkable rhetorical flourish:

'Your pastor has written recently, and in a very touching manner, of the Mass-rocks of the parish, poor mute witnesses to the fidelity of your ancestors despite a persecution as cruel as mean, and as despicable as any from the first to the twentieth century. You will preserve these squalid relics of a sadly glorious past. They will shed a halo around this church. The story of your parish is the story of Ireland, a story of fidelity to religious principle, despite material loss, a story of suffering and of ultimate victory, and you who present this church to God to-day, are acting in the best traditions of our Motherland.'

Dromore's parishioners were, he said, 'no mere group worshipping in a secluded Munster shrine.' They were, instead:

'active members of the greatest society the world had ever known or ever would know. Ever and always, it was morning somewhere, and ever and always, Mass was being offered somewhere on earth [. Today] a new voice [is] added to the chorus of adoration, praise and love. It [will] blend harmoniously with the voices of the countless churches which the sun would shine on in its daily round. ${ }^{, 108}$

Such rhetoric sat uneasily with the socio-economic realities of the parish at the time, but the triumphalist tone was a fitting conclusion to Henchy's own writings about a rural community that he held in great affection, and of the fundraising, volunteering, and organisation that had underpinned the building of the new church. 'The opening of a new church', Lucey commented, 'was an event that did not happen very often: whole generations passed in the parish without witnessing it." ${ }^{109}$

\section{Conclusion}

As much as this article focuses on the socio-economic history of church-building in 1950s Ireland - through examining fundraising, the position of the parish priest within a rural community, and the effects of emigration - it more broadly attempts to write a cultural history of the process of religious architectural production. Through its central themes of architecture, rhetoric and landscape, it explores (Catholic) cultural nationalism from the perspective of a parish priest who enjoyed writing for both his diocesan magazine and his parishioner's local newspaper. Henchy's extensive paper-trail, alongside digitised Census data and the biographical records of the Cork \& Ross diocese, allow us to understand in some more detail the phenomenon of the 'church-building priest' in modern Ireland - an economic and cultural personality among communities that deserves much more scholarly attention. Henchy's writings

\footnotetext{
106 Southern Star, 9th April 1932.

107 Southern Star, 9th April 1932.

108 Southern Star, 7th May 1955.

109 Southern Star, 7th May 1955.
} 
also make clear that his interest in church-building went beyond simply fundraising and bricksand-mortar: the architectural style and furnishings of his new church had political and cultural meanings that were inseparable from Irish history, from the surrounding mountainous landscape, and from contemporary political debate in Ireland and further afield. What was absent, it would seem, was any concern for what we would now term heritage and conservation: Dromore's old church has vanished entirely (it is now a car park). ${ }^{110}$ For Henchy, the renewal of the local community through building a new church evidently outweighed a concern for protecting, in some way, an early nineteenth-century building he dismissed as 'not the fit surroundings for the King of Kings'. ${ }^{111}$ Instead, as he planned his new church, and especially in choosing how its story would be presented at its consecration, Henchy drew from a host of experiences going back to his childhood and his early career - and a range of connections that are only apparent once existing diocesan biographical records are combined to form prosopographical networks. Furthermore, the building of the church was the result of a series of historical conjunctures, from the ruinous state of the old church at Dromore upon Henchy's relocation in late 1953 to the declaration of Pius XII of the Marian Year a few months later. This chronology meant that the church would forever be tied to the particular cultural moment of Marian devotion in Ireland around 1954: Dromore church was, in effect, a Marian shrine.

Research of this kind into what used to be termed Ireland's 'lost decade' is still relatively scarce - and international comparative work is almost non-existent. The building of Dromore church is well served by surviving textual and visual sources, and most of all by an enthusiastic parish priest who documented it with fervour. Yet other church-building projects will inevitably draw from less plentiful wells, and not enough work has been done to answer the important question of how representative were the events in Dromore at this time. Furthermore, though this priest left a considerable archive, there are many missing voices - most of all the ordinary parishioners who donated what they could from their mostly insubstantial wages, who organised fundraising events, and who volunteered their time and energy to help build the church. The surviving sources are also heavily skewed towards male voices - though in practice local women were probably more significant actors in community organisation and fundraising. For many parishioners, whatever their gender, their donations and volunteering, their enthusiasm for constructing a 'Holy Year' cross and a Marian grotto, and their smiles as they posed for photographs in 1954-55, tell us much about popular devotion and the place of religion in daily life - as aspect of Irish cultural life often hard to fully grasp from the perspective of Catholicism in contemporary Ireland.

This article began with the apocalyptic warnings of John A. O'Brien, so typical of the 1950s, that emigration would sound the death knell of the independent Irish state. 'Only their monuments', he prophesied, would be left behind. ${ }^{112}$ One of these would presumably have been Dromore's Hiberno-Romanesque style church, which Henchy, in his writings, situated within a much longer run of conquest, persecution and revival, the material legacies of which were everywhere to be found, he suggested, in the surrounding rural landscape. Where O'Brien showed anxiety, Henchy was filled with confidence and even triumphalism - of an institutional church then at the peak of its political and cultural power. Yet the challenge for the historian today is not, of course, that the 'Irish race' (as O'Brien termed it) was lost. Instead, what has vanished is the Catholic and Marianist religious culture of a particular moment in Irish history that produced such a wealth of public buildings, shrines and grottos. These monuments, which

${ }^{110}$ For the other two new Catholic churches built in west Cork around the same time (Drimoleague and Caheragh), some fragments of the old buildings were saved.

${ }^{111}$ Henchy, 'Our New Church at Dromore', p. 25. This subject is discussed in some more detail in Butler,

'Catholic Power and the Irish City'.

112 O’Brien, The Vanishing Irish, p. 17. 
have been largely left behind, and the culture that produced them, needs now to be better understood. 